\title{
Biodiversity of Sri Lanka
}

\author{
Nimal Gunatilleke $^{1 *}$, Rohan Pethiyagoda ${ }^{2}$ and Savitri Gunatilleke ${ }^{1}$ \\ ${ }^{I}$ Department of Botany University of Peradeniya, Peradeniya. \\ ${ }^{2}$ Wildlife Heritage Trust of Sri Lanka, P.O. Box 66, Mt. Lavinia.
}

\begin{abstract}
This paper reviews the information available on the biodiversity of Sri Lanka, the causes of its degradation and the policies, legal instruments and strategies developed both nationally and internationally for its conservation and sustainable use.

In the first part of this paper, the biodiversity of Sri Lanka at the ecosystem, species and genetic levels is reviewed. At ecosystem level, each major ecosystem is introduced by giving its distribution, vegetation stature where relevant, dominant plant taxa, endemic component, some information on the fauna and finally, a few references to sites studied for that ecosystem. At the species level, the number of taxa in each group, the proportions of endemics and threatened species are highlighted. At the genetic level, genetic variation within and between populations of some indigenous species for which data are available are given, along with a brief overview of genetic diversity in cultivated species.
\end{abstract}

The second part examines causes of loss of biodiversity at the ecosystem level; the third presents information on the policies, legislation and national strategies related to biodiversity conservation in the country and in meeting the international obligations for conservation, sustainable development and sharing of benefits arising from conservation. A strong plea is made on both formal and non-formal education at all levels for using the protected area network as learning laboratories for testing and demonstrating innovative approaches to reconcile the conservation of biodiversity with social and economic development in line with the Man and the Biosphere concept.

Keywords: Conservation, ecosystems, endemics, endemism, species.

\section{INTRODUCTION}

Biodiversity in simple terms is the variety of life on earth at all levels of biological organization. The legally accepted definition adopted by the United Nations Convention on Biological Diversity is 'the variability among living organisms from all sources, including, inter alia, terrestrial, marine, and other aquatic ecosystems, and the ecological complexes of which they are a part; this includes diversity within species, between species and of ecosystems'. These three levels of biodiversity, proceeding from the most obvious (ecosystem and species diversity) to the relatively less obvious genetic or within-species diversity may be defined as follows:

Ecosystem Diversity: The sum total of all interrelated and interacting organisms and all the components of the physical environment (climate, soil, water, fire, rocks, wind, landscapes etc.) that function together as one unit. Depending on the organisms and environment that make up an ecosystem, different types of ecosystems may be identified. It is this variability among ecosystems that is referred to as ecosystem diversity.

Species Diversity: The variation among species is recognized as species diversity.

Genetic Diversity: The genetic variation among individuals of a population and that among all the different populations of the same species comprises the total genetic variation of that species.

This paper is presented in three parts. Part one, which includes a substantial component of the paper, identifies Sri Lanka's biodiversity at the ecosystem, species and genetic levels. At the ecosystem level, each major ecosystem is introduced by giving its distribution, vegetation stature where relevant, dominant plant taxa, endemic component, some information on the fauna and finally, a few references to sites studied for that ecosystem. At the species level, the number of taxa in each group, the proportions of endemics and threatened species are highlighted. At the genetic level, genetic variation within and between populations of some indigenous species for which data are available are given along with a brief overview of genetic diversity in cultivated species. 
The second part examines causes of loss of biodiversity at the ecosystem level; the third presents information on the policies and legislation related to biodiversity conservation in the country and international obligations for conservation, sustainable development and sharing of benefits arising from conservation.

\section{Ecosystem diversity of Sri Lanka}

Despite its small size, Sri Lanka has a rich ecosystem diversity because of its topographic and climatic heterogeneity as well as its coastal influence. These natural/semi-natural ecosystems are broadly i) the marine and maritime or coastal ecosystems, ii) natural forest ecosystems, iii) natural and semi-natural grassland ecosystems, and iv) the inland wetland ecosystems.

Table 1 lists the diversity of the different ecosytems and their extents, where this information is available. In addition, there are other man-made ecosystems such as agro-ecosystems (including home gardens) that structurally resemble natural forests, and cash-crop fields and plantations.

The following ecosystems in Sri Lanka have been internationally recognized for their outstanding biological wealth and their current conservation status.

i. Sinharaja lowland and lower montane rain forest is a Natural World Heritage Site and also an International Man and the Biosphere Reserve. ii. Hurulu dry mixed evergreen forest and the Kanneliya -Dediyagala - Nakiyadeniya lowland rainforest complex are International Man and the Biosphere Reserves.

iii. Western Ghats and Sri Lanka together form one of the 34 Biodiversity Hotspots ${ }^{1}$.

iv. Bundala, Anavillundawa and Maduganga estuary and mangrove ecosystem are Ramsar Wetland Sites.

v. 41 of the 83 wetland sites in Sri Lanka are included in the Asian Directory of Wetland Sites ${ }^{2}$.

The marine ecosystems are represented by coral reefs and sea grass beds and the ocean that surrounds Sri Lanka (Figure 1).

Coral reefs, both near-shore reefs (mostly fringing, sandstone, rock and boulder) and well-developed off-shore reefs are found along 2-3 \% of the island's coastline. They have a rich diversity of corals with about 183 species from 68 genera, principally Acropora, Montipora, Porites, Favia, Favites, Pocillopora, Goniastrea, Platygyra and Leptoria. Green, red, and brown algae, mollusks, sea cucumbers, sea anemones, lobsters and reef fish abound in these reefs. It is estimated that about 1000 species of fish inhabit Sri Lanka's coral reefs $^{3}$.

Sea-grass beds are found in calm shallow seas, estuaries and lagoons around the island where 12 species

Table 1: Ecosystem diversity and their extents in Sri Lanka

\begin{tabular}{|c|c|c|c|}
\hline $\begin{array}{c}\text { Aquatic ecosystem } \\
\text { diversity }\end{array}$ & $\begin{array}{l}\text { Present } \\
\text { extent (ha) }\end{array}$ & $\begin{array}{c}\text { Terrestrial ecosystem } \\
\text { diversity }\end{array}$ & $\begin{array}{c}\text { Present } \\
\text { extent (ha) }\end{array}$ \\
\hline Coastal Ecosystems & & Natural forest ecosystems & \\
\hline 1. Coral reefs & not available & 1. Tropical lowland wet evergreen & \\
\hline 2. Sea grass beds & 23,819 & forests or lowland rain forests & 141,506 \\
\hline 3. Salt marshes & 33,573 & 2. Tropical submontane forests & 68,616 \\
\hline 4. Mangroves & 12,189 & 3. Tropical montane forests & 243,886 \\
\hline 5. Sea shores/beeches & not available & 4. Tropical moist evergreen forests & $1,090,981$ \\
\hline 6. Mud flats & not available & 5. Tropical dry mixed evergreen forests & 464,076 \\
\hline 7. Lagoons and estuaries & 158,017 & 6. Thorn scrub forests & not available \\
\hline \multirow[t]{2}{*}{ 8. Sand dunes } & 7,606 & & \\
\hline & & Natural grassland ecosystems & \\
\hline Inland Aquatic Systems & & 1. Wet patanas & not available \\
\hline 1. Fresh water marshes & $10,000 * *$ & 2. Dry Patanas* & 65,000 \\
\hline 2. Rivers and streams & & 3. Savannas* & not available \\
\hline Riverine Forests & 22,435 & 4. Thalawas* & not available \\
\hline \multirow[t]{2}{*}{ 3. Reservoirs* } & 170,000 & 5. Damanas* & 10,000 \\
\hline & & 6. Villu & \\
\hline
\end{tabular}

* Man-influenced ecosystems. ** Also includes the villus. 


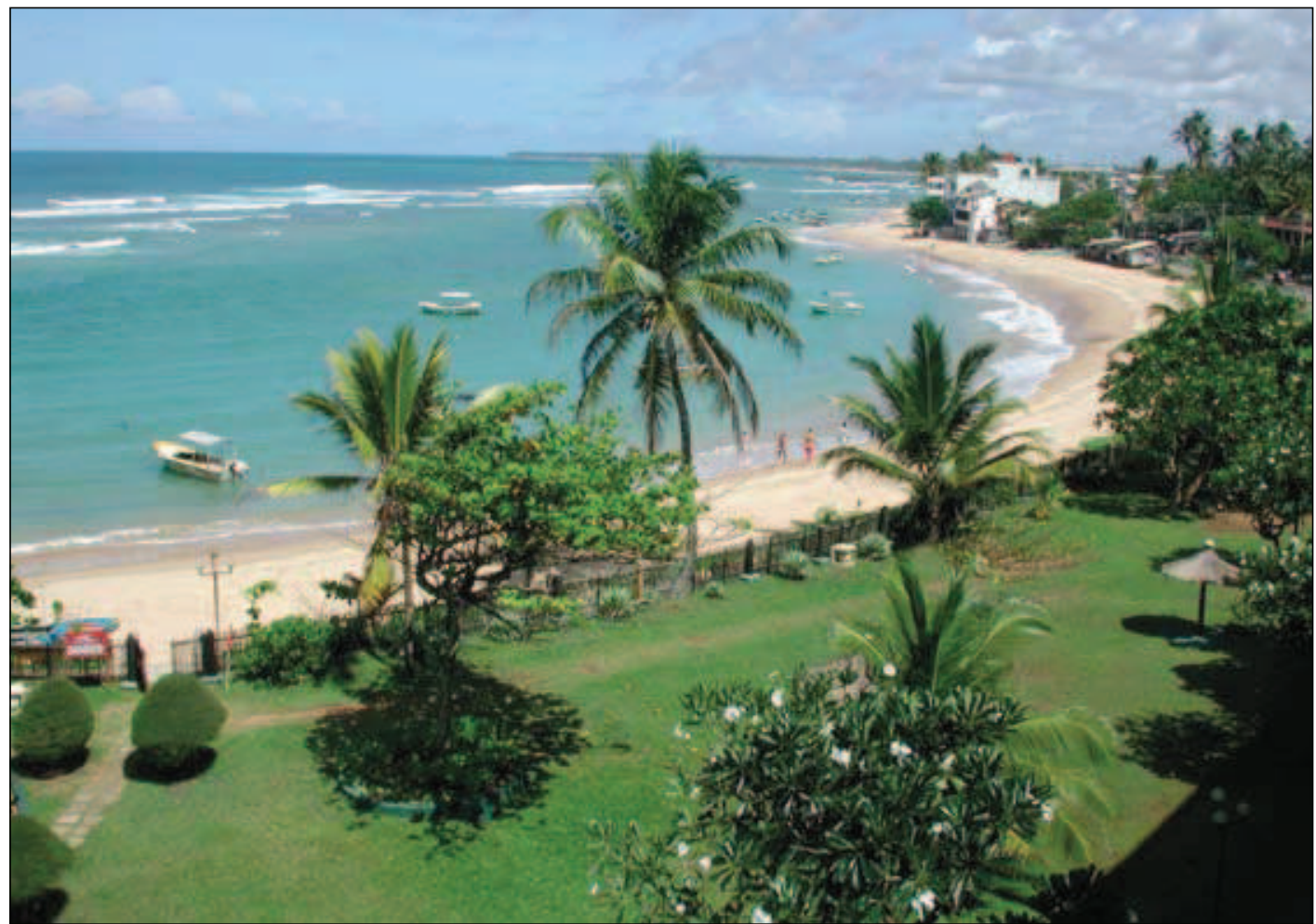

Figure 1 : Hikkaduwa marine sanctuary with near-shore coral reef communities. These together with sandy beaches and the fishing harbour have increased the anthropogenic pressure on this fragile maritime natural resource.

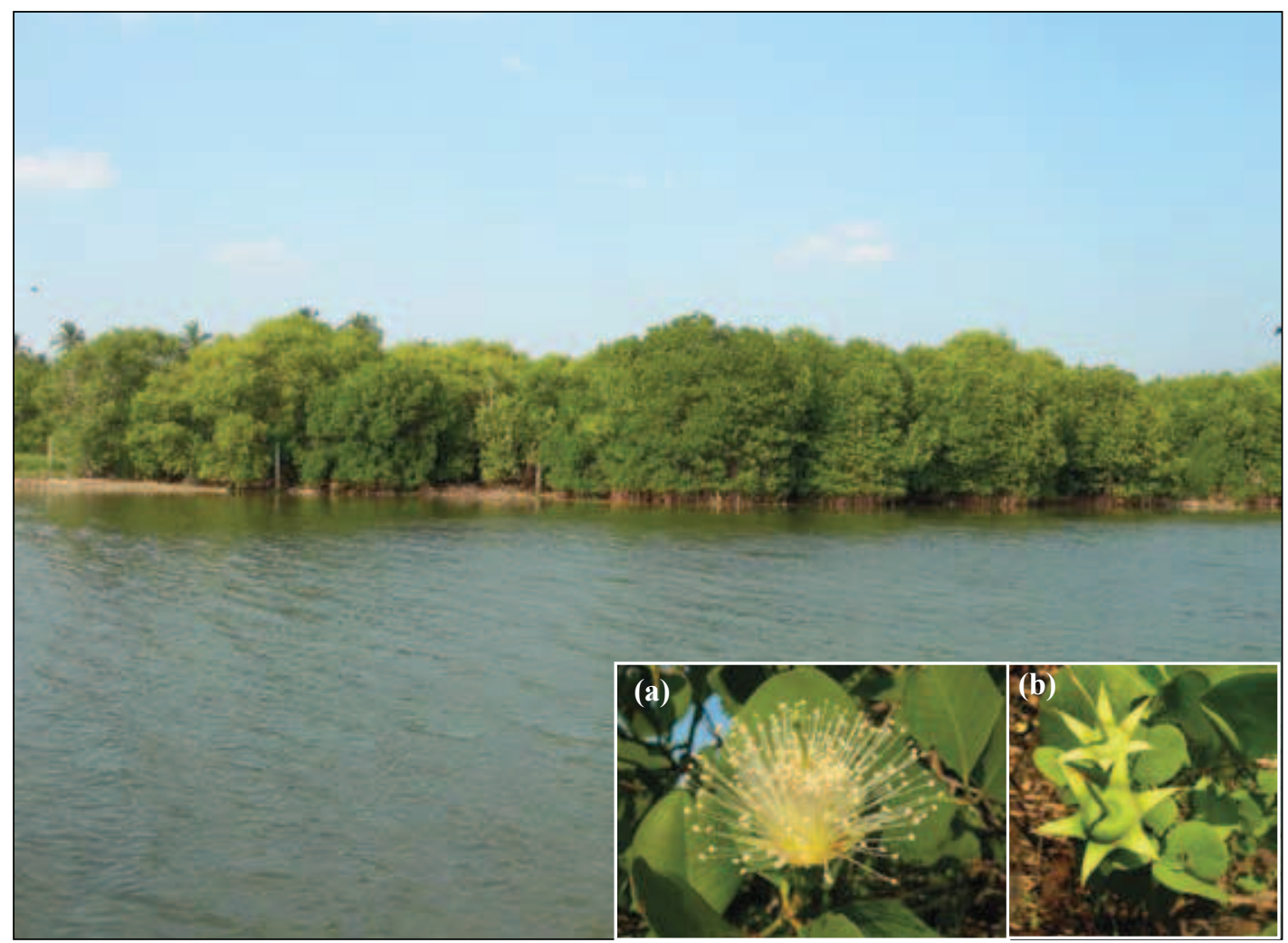

Figure 2: A mangrove formation dominated by Rhizophora spp. fringing the Negombo Lagoon. Inset: a flower and a fruit of Sonneratia caseolaris. 


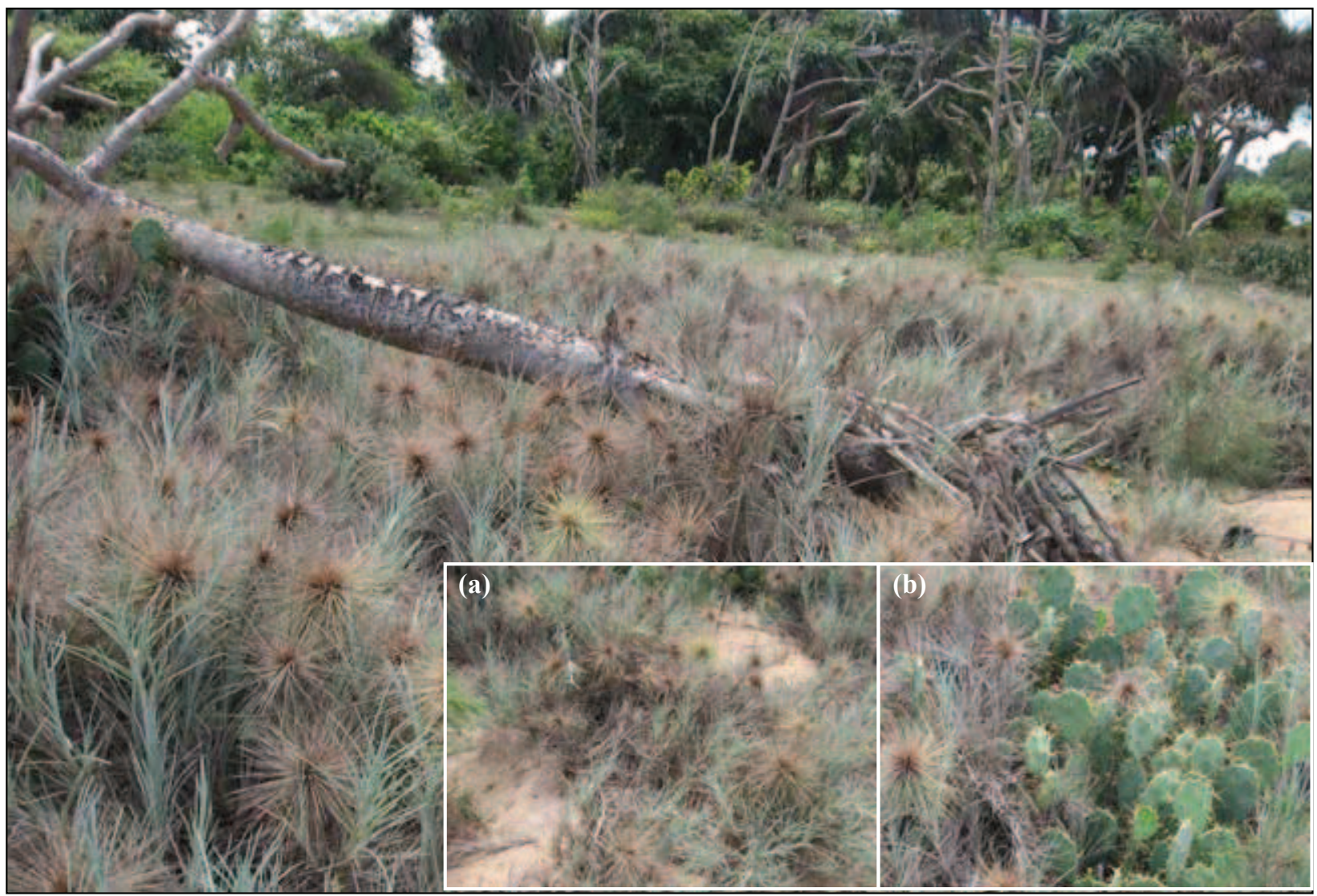

Figure 3 : Sea shore vegetation dominated by a) Spinifex littoreus which is being invaded by the prickly pear b) Opuntia sp., an exotic xerophyte. In the background are the woody elements of the sea-shore vegetation dominated by Pandanus sp. which along with other shrubby vegetation acts as a barrier to coastal erosion and even tsunami.
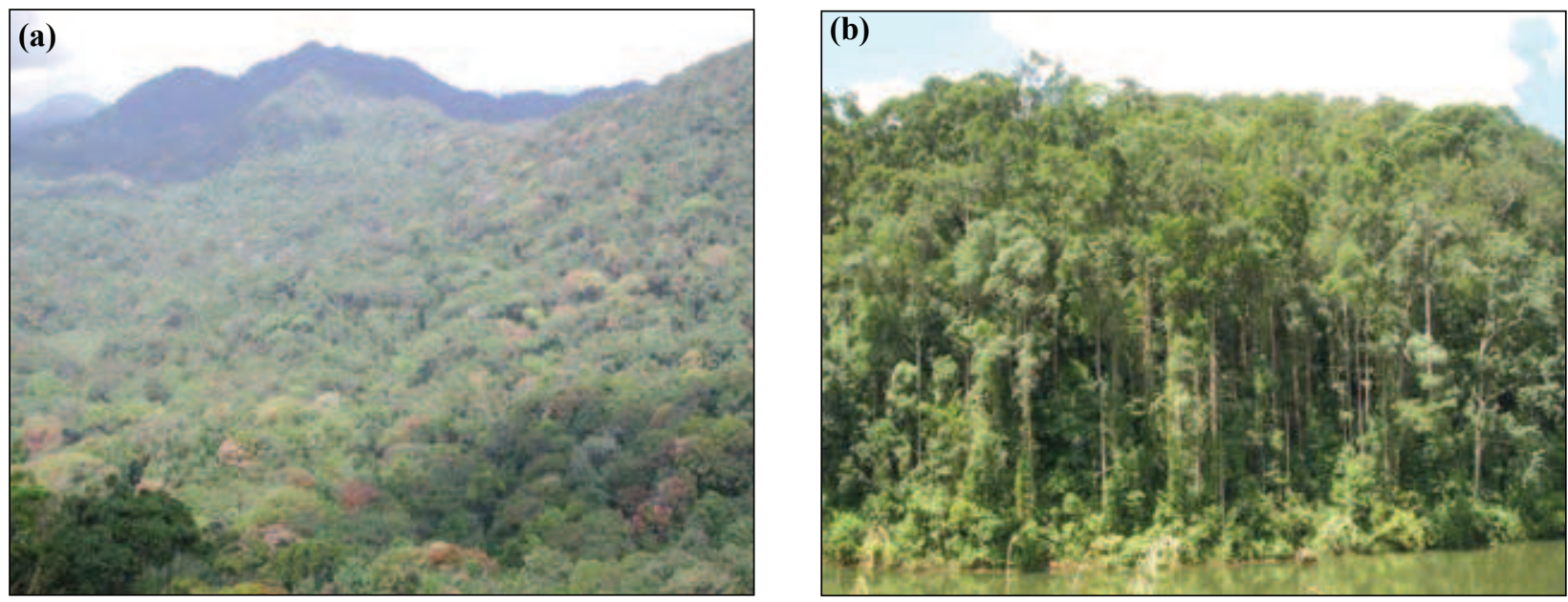

Figure 4 : (a) Canopy of the lowland rain forest of Sinharaja World Heritage Site dominated by Doona (Shorea) and Mesua species exhibiting habitat specialization leading to greater species richness. (b) A vertical profile as seen in a forest fragment near Kukule Ganga reservoir. 
of angiospermous halophytes have been recorded so far. Amongst them, Enhalus acoroides, Thalassia hemprichii, Halophylla and Najas are typical of this ecosystem. These species have rhizomatous stems and thin floating leaves ranging widely in size and shape among the taxa ${ }^{4,5}$. They support a diversity of organisms, including fish that directly feed on sea grass, while others such as peneid shrimp larvae feed on grass detritus. Sea-grass beds also provide habitats for sea turtles and dugong ${ }^{3}$.

The near-shore and off-shore waters of the Indian Ocean surrounding Sri Lanka are inhabited by predatory fish such as reef sharks, and a range of food and shell-fish, lobsters, upon which the marine fishery is dependent. In addition, there are about 38 species of marine mammals comprising one locally depleted species of dugong and 37 cetaceans including the sperm whale, the blue whale and over 20 species of dolphins ${ }^{3}$.

\section{a) The maritime ecosystems:}

These are influenced by their proximity to the sea and include the salt marshes, mangroves and seashore or strand vegetation.

The salt marshes are confined to the inter-tidal flats frequently inundated with salt water in the northwestern and southeastern arid zones of Sri Lanka, covering an estimated area of $34,000 \mathrm{ha}^{3,4}$. They are dominated by the halophytic or salt-loving plants Halosarcia indicum, Salicornia brachiata, Sueda maritima, and S. monoica, which are confined to this ecosystem. In addition, there are about 17 species of salt-marsh associates, which may be found elsewhere as well ${ }^{5,6}$. Marshes also provide habitats for waterfowl and milkfish. On inundated higher ground the salt marshes give way to a distinctive, sandy seashore vegetation (see below).

The mangroves, influenced by tidal amplitude, scattered, and restricted to coastal lagoons and estuaries; they are best seen near Jaffna, Batticaloa, Kalpitiya, Rekawa and Trincomalee (Figure 2). Mangroves are dominated by the plant families Rhizophoraceae, Acanthaceae and Avicenniaceae and the tree species Rhizophora apiculata, Rhizophora mucronata, Ceriops tagel, Bruguiera gymnorhiza, Acanthus illicifolius, Lumnitzera racemosa, Avicennia officinalis and Avicennia marina. Altogether, 18 true mangrove species have been described from Sri Lanka ${ }^{7}$. All these species are adapted to grow under saline conditions and a fluctuating water table. Nypa fruticans, Sonneratia caseolaris, R. apiculata and Bruguiera sexangula have been reported from riverine mangals, while $R$. mucronata, C. tagal, $S$. alba and A. marina dominate fringing mangals in the dry and intermediate zones ${ }^{8,9}$. Other studies have been done on mangroves in the west coast ${ }^{9-13}$, the northern part of the country ${ }^{14}$ and in relation to their conservation ${ }^{10-15}$.

Mangroves, while harbouring a rich migrant (both from inland and sea) and resident faunal component 9,15-20 including finfish, shellfish, clams, crabs, oysters and shrimp, also provide nursery grounds for numerous marine organisms and roosting sites for birds ${ }^{16-20}$.

The sea-shore vegetation is seen above the high-water mark on sandy, gently sloping beaches. The vegetation grades from a very short-statured creeping form near the seafront, through herbaceous erect shrubs, to a $10-15 \mathrm{~m}$ tall littoral woodland (Figure 3 ). The dominant vegetation is Ipomea pescaprae in the wet zone of the country and the grass Spinifex littoreus in the drier parts. The common herbaceous species here include those of Vernonia, Hedyotis, Phyllanthus and Crotalaria; the shrubs include those of Scaevola, Clerodendrum, Morinda and Calotropis; and the tree component comprises Pandanus spp., Barringtonia asiatica, Calophyllum inophyllum and Thespesia populnea. These species have special adaptations to root in unconsolidated sandy soil, and to withstand strong winds laden with salt spray and saline soil-moisture conditions. The seeds of most species are also adapted to wind or water dispersal.

Sri Lanka has a coastline of $1,585 \mathrm{~km}$, and many of the beaches fringing the island are wide and sandy, providing ideal habitats for nesting turtles. Five species of turtles Caretta caretta, (Loggerhead turtle), Lepidochelys olivacea (Olive Ridley turtle), Eretmochelys imbricata (Hawksbill turtle), Chelonia mydas (Green turtle) and Dermochelys coriacea (Leatherback turtle) use this habitat for nesting ${ }^{21}$.

\section{b) The inland forest ecosystems:}

They range from wet (aseasonal) zone rainforests to thorn scrub in the arid zone. Between these extremes are forests in the seasonally dry and intermediate zones. Based on the patterns of distribution of the angiosperm flora and their endemicity, 15 different floristic regions have been recognized in the island ${ }^{22}$. The diversity of forest ecosystems and their extents are given in Table 1, and salient features of each are described below.

Tropical lowland wet evergreen forests or lowland rain forests, restricted to the southwest of the island, up to a mean elevation of $900 \mathrm{~m}$, and are at present highly fragmented ${ }^{23}$. Sinharaja, the largest block of relatively undisturbed forest and the selectively logged KanneliyaDediyagala-Nakiadeniya group of forests, best exemplify 
them (Figure 4). Reaching 30-45 $\mathrm{m}$ in height, they are dominated by the families Dipterocarpaceae, Clusiaceae, Sapotaceae, Bombacaceae and Myrtaceae. At the lower elevations $(<100 \mathrm{~m})$, Dipterocarpus zeylanicus and D. hispidus, and at higher elevations (>100 m) Mesua ferrea and Shorea trapezifolia, dominate the canopy of these forests. In the sub-canopy, the common species are Cullenia rosayroana, C. zeylanica and Myristica dactyloides, and in the understorey tree layer Xylopia championii and Garcinia hermonii. Large leaves, drip tips on leaves, buttresses, cauliflory, drooping young twigs, colourful young leaves and fewer lianas and epiphytes characterize its vegetation.

In these forests as much as $60-75 \%$ of the tree species are endemic to Sri Lanka. Most of their tree species are soft and medium hardwoods and were logged primarily for plywood manufacture until a moratorium on logging was imposed by the government in 1989 . Two of the most valuable hardwood species in these lowland rainforests are Calamander (variegated ebony, Diospyros quaesita) and in wet zone flood-plain forests, Nedun (Pericopsis mooniana).

In this ecosystem, various aspects of the vegetation, mostly trees and selected faunal groups have been studied. These forests are the most diverse and the richest in endemic biota among terrestrial ecosystems ${ }^{24}$, 25. Some among the vegetation studied include those at Sinharaja $^{26}$, Kanneliya ${ }^{25,27,28}$, Kottawa ${ }^{25,27}$, Gilimale ${ }^{25,27}$, Delwala $^{29}$ and almost all the forests $>200 \mathrm{ha}^{30}$. Spacio-temporal dynamics of the Sinharaja forest is being studied using a 25 ha Forest Dynamics Study Plot in Sinharaja ${ }^{31}$. These studies have revealed that most tree species in them are specialists and exhibit habitat associations in relation to the topographic variation of the land form.

The vertebrate fauna in lowland rainforests have been studied better than most invertebrate groups and noteworthy among them are studies on the small mammals $^{32}$, avifauna ${ }^{33-35}$, reptiles ${ }^{36}$, fishes ${ }^{37-39}$ and amphibians $\mathrm{s}^{40-42}$.

The bird flocks recorded in Sinharaja are among the largest reported in terms of numbers per flock containing many endemic and threatened species ${ }^{34-35}$.

Although some information of the invertebrate fauna in lowland rain forests has been reported, there is a great dearth of information or none at all with respect to other taxonomic groups. Studies among the invertebrate groups include those on butterflies ${ }^{43,44,44 a}$, spiders $^{45}$, ants ${ }^{46,47}$, fresh water crabs ${ }^{48}$ and land snails ${ }^{49,50}$. The monotypic endemic relict ant Aneuretus simoni is also found in this ecosystem.

The lower montane forests are confined to middle elevations (900-1500 m) of the Peak Wilderness, Knuckles (Dumbara hills), Namunukula and the Rakwana-Deniyaya ranges (Figure 5). Their canopies are about 20-25 $\mathrm{m}$ high, dominated by the families Dipterocarpaceae, Clusiaceae and Myrtaceae, with the following soft and medium hardwood species being dominant: Shorea gardneri, Calophyllum spp. Cryptocarya wightiana, Myristica dactyloides and Syzygium spp. The proportion of endemic tree species here is about $50 \%{ }^{51-55}$. The herbaceous, shrub and epiphytic flora have not been studied in depth: preliminary surveys however, indicate that they may represent a higher proportion of endemics in this ecosystem. Most species of the endemic genus Stemonoporus show a localized distribution in these montane forests ${ }^{22,56,57}$.

The Knuckles (Dumbara Hills) range shows much heterogeneity in its vegetation distribution in relation to the monsoonal climatic regimes to which it is exposed. The NE flanks are seasonally somewhat drier during the SW monsoonal period as compared with the SW-facing slopes which are more moist throughout the year.

These lower montane forests have not been investigated extensively, even though some of the richest habitats are represented in this ecosystem; among them, Floristic Region 9 the foothills of Peak Wilderness, spanning from Maskeliya and the Kelani valley in the northwest, through Ambagamuwa around Kitulgala in the south and eastwards to Maratenna above Balangoda- encompasses a centre of exceptionally high endemism ${ }^{22}$.

Tree vegetation of the lower montane forests studied include parts of the Knuckles, Eastern Sinharaja ${ }^{26,55}$ and different locations in the Peak Wilderness ${ }^{51-54}$.

Studies on the fauna in these ecosystems are discussed, along with those in the montane forests, in the next section.

The montane forests, restricted to the uppermost elevations of the country $(>1500 \mathrm{~m})$, are dominated by the Clusiaceae, Myrtaceae, Lauraceae, Symplocaceae and Rubiaceae. The common tree species in them are Calophyllum walkeri, C. trapezifolium, Syzygium revolutum, S. rotundifolium, S. umbrosum, Symplocos cochinsinensis, Neolitsea fuscata, Cinnamomum 
ovalifolium, Litsea ovalifolia and Actinodaphne speciosa. In most areas, the understorey of the forest is dense and dominated by species of Strobilanthes, bamboo and Coleus. About $10 \mathrm{~m}$ tall, short-statured trees with gnarled twisted branches, an abundance of epiphytes dominated by mosses, leafy liverworts, ferns and orchids, colourful young foliage, relatively small, thick, leathery leaves and absence of drip tips are distinguishing features of its vegetation (Figure 6). With increase in elevation and windy conditions the canopy species become quite stunted giving way to pygmy forests.

The bryophyte flora of island is the richest in the lower montane and montane ecosystems, but relatively under-explored ${ }^{59,60}$.

In this ecosystem studies on phytosociology have been carried out in the Horton Plains ${ }^{61}$, Hakgala Strict Nature Reserve ${ }^{62}$, and the Knuckles ${ }^{63}$ forest die back in Horton Plains ${ }^{64-66}$, Pidurutalagala ${ }^{67}$ and Kobonilgala in Knuckles $^{68}$.

These rainforest ecosystems too, harbour a substantial proportion of endemic species of amphibians ${ }^{41,42}$, freshwater crabs ${ }^{48}$ and land snails ${ }^{49,50}$.

The faunal diversity in the lower montane and montane forests is quite outstanding. Some taxa are confined or restricted to one or few locations either in the Rakwana-Deniyaya hills, Central Highlands or the Knuckles. A few examples of such localized distributions are exemplified by Ceratophora spp $^{69}$ (C. erdeleni and C. karu in Eastern Sinharaja; C. tennenti in Knuckles), the direct-developing shrub frogs, Philautus spp. ${ }^{70,71}$ (P. schmarda and P. variabilis Central Highlands only; $P$. macropus and $P$ steineri from Knuckles only; $P$. lunatus and $P$. poppiae from Handapan Ella Plains only), the freshwater shrimp Lancaris $\operatorname{spp}^{72}(L$. singhalensis from only Horton Plains and Nuwara Eliya; and L. kumariae near Rozella), and the fresh water crabs $^{73}$ (Ceylonthelphusa diva from Knuckles; $C$. savitriae and Perbrinckia rosae from Morningside; and P. gabadagei from Peak Wilderness). Other studies carried out at Knuckles on the herpetofauna, agamid lizards in relation to disturbance, amphibians and bird flocks have also been published ${ }^{74-76}$.

Tropical moist evergreen forests, about $25-30 \mathrm{~m}$ tall, represent the transition or ecotone between forests in the aseasonal and seasonal climates. They bear similarities in species composition to both the tropical lowland wet evergreen forests and the tropical dry mixed evergreen forests and some species of their own. Fragments of this forest type are seen at Barigoda near Kurunegala and Daragoda near Moneragala, and more extensive areas in Randenigala and Samanalawewa. The dominant families here are Anacardiaceae, Sapindaceae, Euphorbiaceae and Moraceae. The dominant species are Mangifera zeylanica, Canarium zeylanicum, Filicium decipiens, Dimorcarpus longan, Nothopegia beddomei and Gironniera parvifolia. Lianas are abundant in this forest type. Only about $17 \%$ of the tree species in them are endemic to Sri Lanka. One of these endemics is Hopea brevipetiolaris $^{77}$ on the crest of Doluwakanda, which is its only habitat. A few of the characteristic elements of this ecosystem are Tetrameles nudiflora, Antiaris toxicaria, Artocarpus gomezianus and Pterygota thwaitesii ${ }^{25}$.

In tropical moist evergreen forest ecosystems, the vegetation has been studied extensively in the Victoria-Randenigala-Rantambe (VRR) Sanctuary ${ }^{78}$, Samanalawewa ${ }^{79}$, Barigoda forest ${ }^{25,27}$ near Kuliyapitiya, Daragoda forest ${ }^{25,27}$ near Moneragala, Wasgomuwa National Park ${ }^{80-82}$, Kahalla ${ }^{83}$ and Maduru Oya Forest Reserve $^{84}$.

Tropical dry mixed evergreen forests represent $54 \%$ of the island's natural forest cover and $16 \%$ of its total land area. Typical examples of them are seen in the North, Eastern, North Central, North-Western and Southern Provinces. In the best stands they are about $25 \mathrm{~m}$ tall, but shorter in those towards the arid zone (Figure 7). The families Euphorbiaceae, Sapindaceae, Ebenaceae, Sapotaceae, and Rutaceae dominate them. The dominant canopy species are Manilkara hexandra, Chloroxylon swietenia, Schleichera oleosa, and Pleurostylia opposita, while those in the understorey tree layer are Pterospermum suberifolium, Drypetes sepiaria and Dimorphocalyx glabellus. They comprise a mixture of evergreen and deciduous canopy species. In general, the latter are found in the canopy, shedding their leaves during the late dry period, allowing much light to filter to the forest floor. This enables grass and herbaceous species to flourish at the onset of the rainy season before new foliage on denuded canopy trees emerges. The appearance of these forests differs seasonally and depicts an annual cyclical variation in floristic diversity of the ground vegetation. Leaves of plant species here are small, without drip tips; many have compound leaves. The tree trunks branch lower down and show no buttresses, compared with those in rainforests. Epiphytes and lianas are relatively sparse in this forest type.

A significant proportion of this flora is similar to that of India, and only about $13 \%$ of the tree species are endemic to Sri Lanka. These forests are rich in quality 

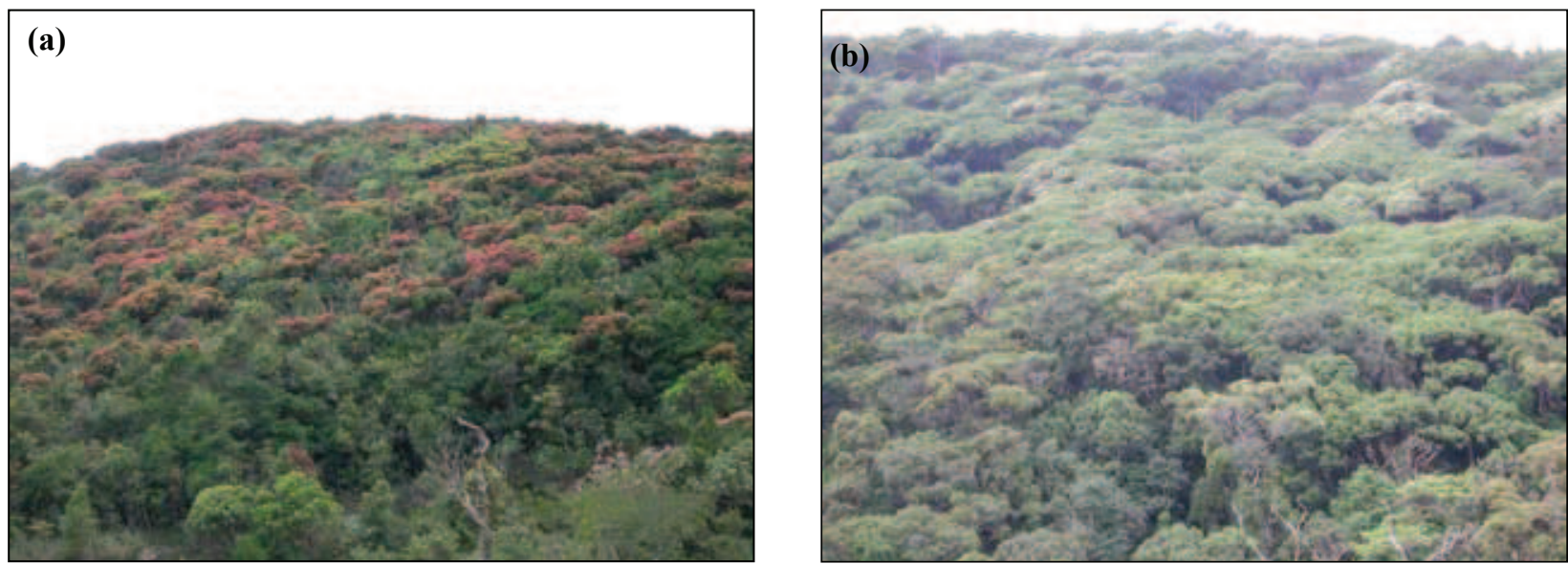

Figure 5 : Lower montane rain forests a) in the Knuckles (Dumbara) conservation forest. These windswept hence low-statured forests are dominated by Syzigium species (in pink flush). b) Lower montane forests in eastern Sinharaja dominated by Doona (Shorea) gardneri.
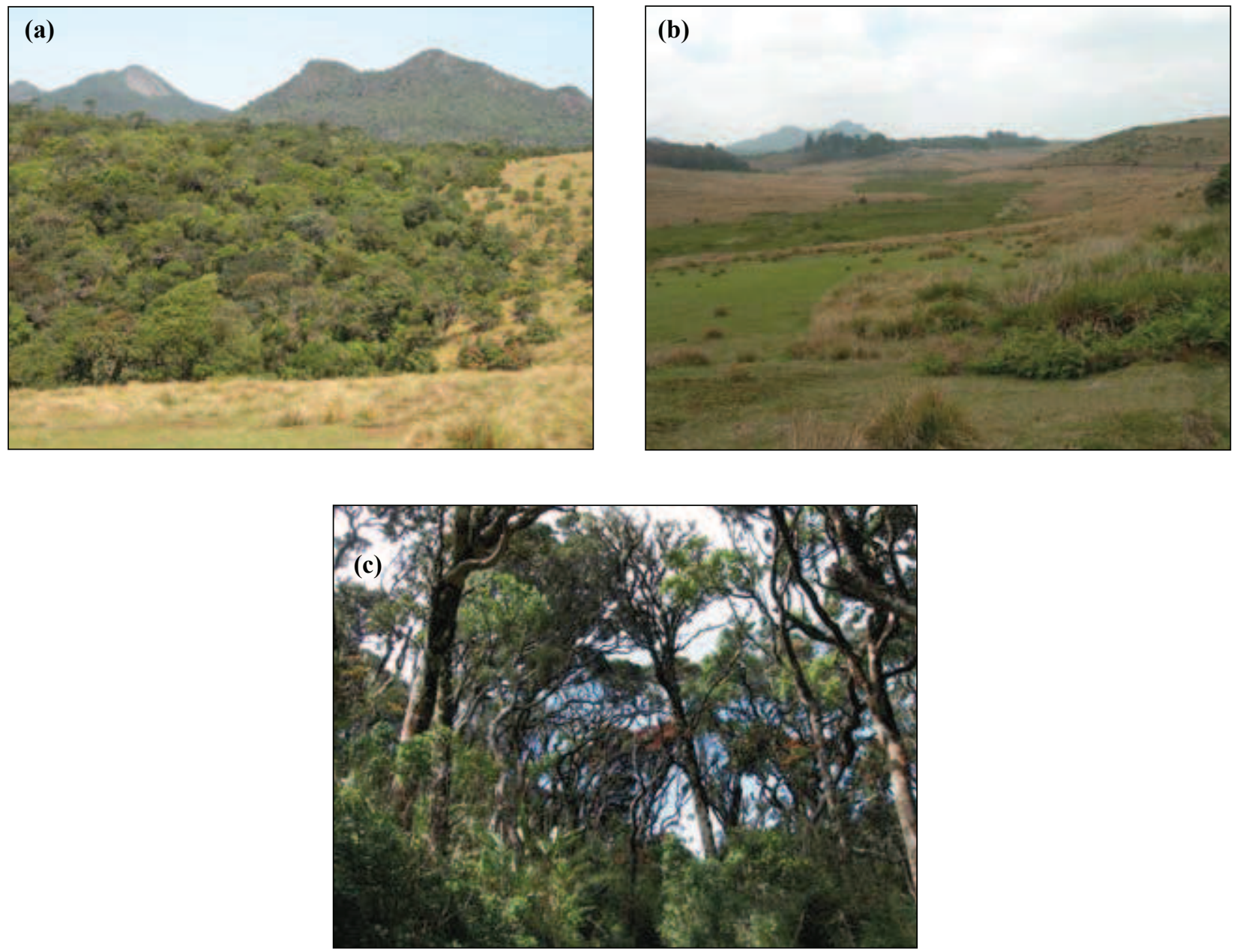

Figure 6 : a and b) Wind-swept and short-starured montane cloud forests interspersed with wet patana grasslands in a mosaic. c) Montane forest trees with characteristic gnarled tree crowns 
hardwood species suitable for sawn timber and for this reason and for agricultural expansion, they have been clear-felled in the past and are now mostly restricted to protected areas.

In tropical dry mixed evergreen forest ecosystems, vegetation surveys have been done at Kahalla $^{83}$, Ritigala ${ }^{25,27,85,86}$, Maduru Oya Reserve ${ }^{84}$, Polonnaruwa ${ }^{89,90}$, Wasgamuwa ${ }^{80-82}$, Irrigation area of the Lower Walawe Basin ${ }^{91}$, and Wilpattu ${ }^{92}$.

Thorn scrub forests found in the arid zone are typical of the vegetation in Yala in the southeast and Mannar region in the Northern Province. As the name implies, thorny species are abundant here and reach to about $5 \mathrm{~m}$ in height showing no species stratification. Its dominant families are Salvadoraceae, Mimosaceae, Euphorbiaceae and Rhamnaceae. The dominant species are Salvadora persica, Acacia planifrons, Dichrostachys cinerea, Bauhinia racemosa, Eugenia bracteata, Phyllanthus polyphyllus, and Zizyphus oenoplia. Endemic plant species are almost absent in these forests.

In Yala ${ }^{93,94}$ and Bundala $^{95}$, this ecosystem together with its neighbouring grasslands and water bodies, harbour large mammals (leopard, elephants, spotted deer, sambhur and wild pig, primates etc.), numerous water-and inland bird species (both migrant and resident) reptiles, amphibians and a diversity of invertebrate species.

\section{c) Natural / Semi Natural Grasslands :}

Very broadly, based on elevation, climate, plant composition and degree of disturbance, six types of grassland ecosystems are recognized in Sri Lanka ${ }^{96,97}$ (Table 1). They are the following:

The wet patana grasslands, found around and above $1800 \mathrm{~m}$ altitude, are best seen in Horton Plains and around Nuwara Eliya (Figure 8). They are dominated by the tussock grass species Chrysopogon nodulibarbis and Arundinella villosa on higher ground and Garnotia exaristata and the dwarf bamboo, Sinarundinaria densifolia, close to waterways. A diversity of delicate, small herbaceous species with colourful flowers grow among the grasses. They include Pedicularis zeylanica, Satyrium nepalense, Exacum walkeri, Osbeckia spp., Ranunculus spp. (some very seasonal) and the fern Pteridium revolutum. Rhododendron arboreum ssp. zeylanica about $2 \mathrm{~m}$ tall, often displaying spectacular brilliant red flowers, the shorter Gaultheria leschenaultii whose leaves smell of wintergreen and the invasive spiny Ulex europaeus, are the widely scattered woody species in these grasslands (Figure 9).
During less wet periods of the year, February to April, these grasslands are subject to accidental fires. These fires, ground frost in January/February, a high water table and herbivory all contribute to the maintenance of these grasslands.

In the early 1960 s about 120 ha of wet patana grassland were used for cultivation of seed potato by the Department of Agriculture and later abandoned, following which the area was gradually converted to a carpet-like grassland dominated by the exotic Penesetum sp. This grassland, with its vegetation growing close to the ground, does not provide environmental conditions and microhabitats for the herbaceous flora to thrive, unlike among the tussock grasses of the natural wet patana. Therefore, its floristic richness is much less, and consequently its faunal diversity as well.

Sambhur, wild boar and black-naped hare feed in these grasslands at night but rest in the adjacent forests during the day. The grassland/forest complex provides them an ideal system for survival. Among the other animals recorded ${ }^{98}$ are three endemic freshwater crabs (Ceylonthelphusa scansor, Perbrinckia punctata, P. glabra), the endemic shrimp (Lancaris sinhalensis) and among the amphibians Philautus microtympanum, Fejervaryia greenii, Microhyla zeylanica and Polypedates eques inhabit the streams and/or their immediate environs.

Among the wet patana grasslands, the flora and fauna has been best studied in Horton Plains ${ }^{98-100}$.

The dry patana grasslands, located between 500 $1000 \mathrm{~m}$ elevation, are relatively widespread, occurring in the Uva basin, and around Gampola, Nawalapitiya, Hantana and Rakwana. These grasslands have resulted from the removal of tree vegetation for agriculture and subsequent abandonment (Figure 10). The dominant grass species in them are Cymbopogon nardus and Themeda tremula, both forming tussocks. Other species seen among the grasses include a large number of tall composite herbs (Blumea spp., Vernonia spp. etc.) and semi-woody to woody shrubs (Cassia spp., Crotalaria spp., Lantana camara, Osbeckia octandra, Psidium guajava, Wikstroemia indica).

During the dry months these dry patanas are purposely burnt to obtain fresh grass for fodder or to hunt animals. Their very existence is a result of fire. Much of these grasslands are now converted to agricultural land and Pinus and Eucalyptus plantations. They are also being taken over by the aggressively competitive exotic fodder grass Panicum maximum and invasive species 

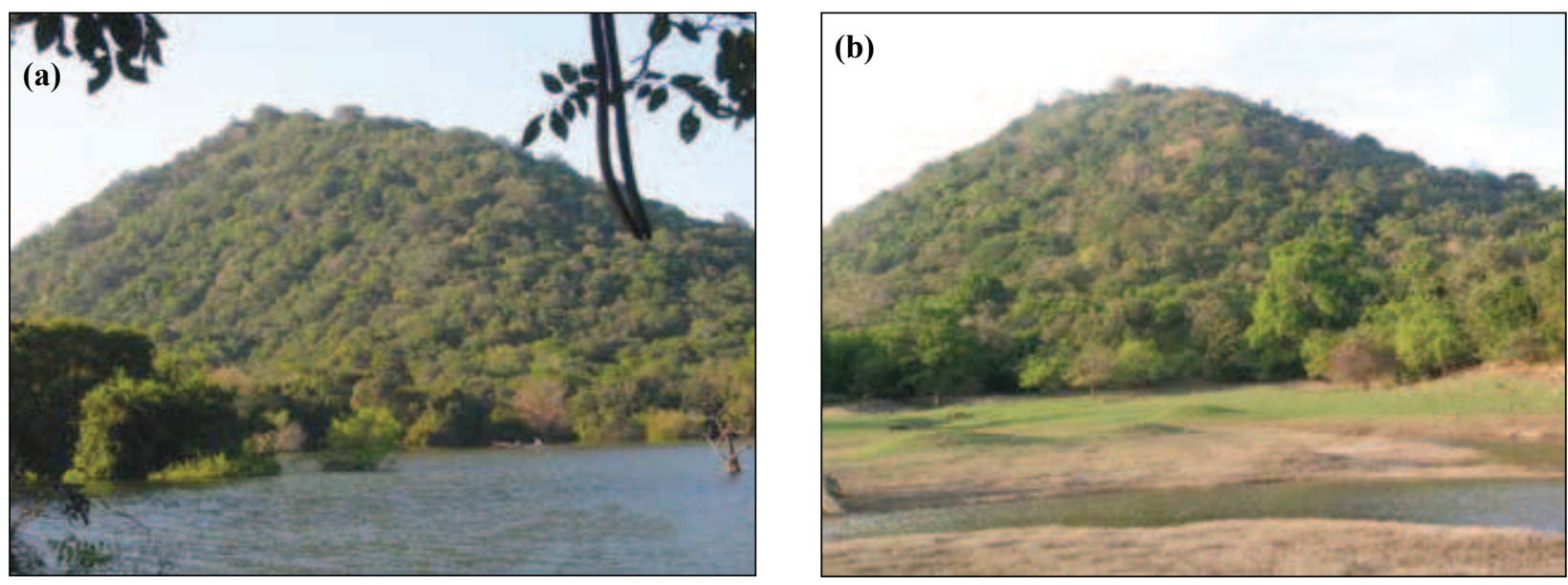

Figure 7 : Dry mixed evergreen forest along a small hill in Giritale during a) the wet and b) dry season.

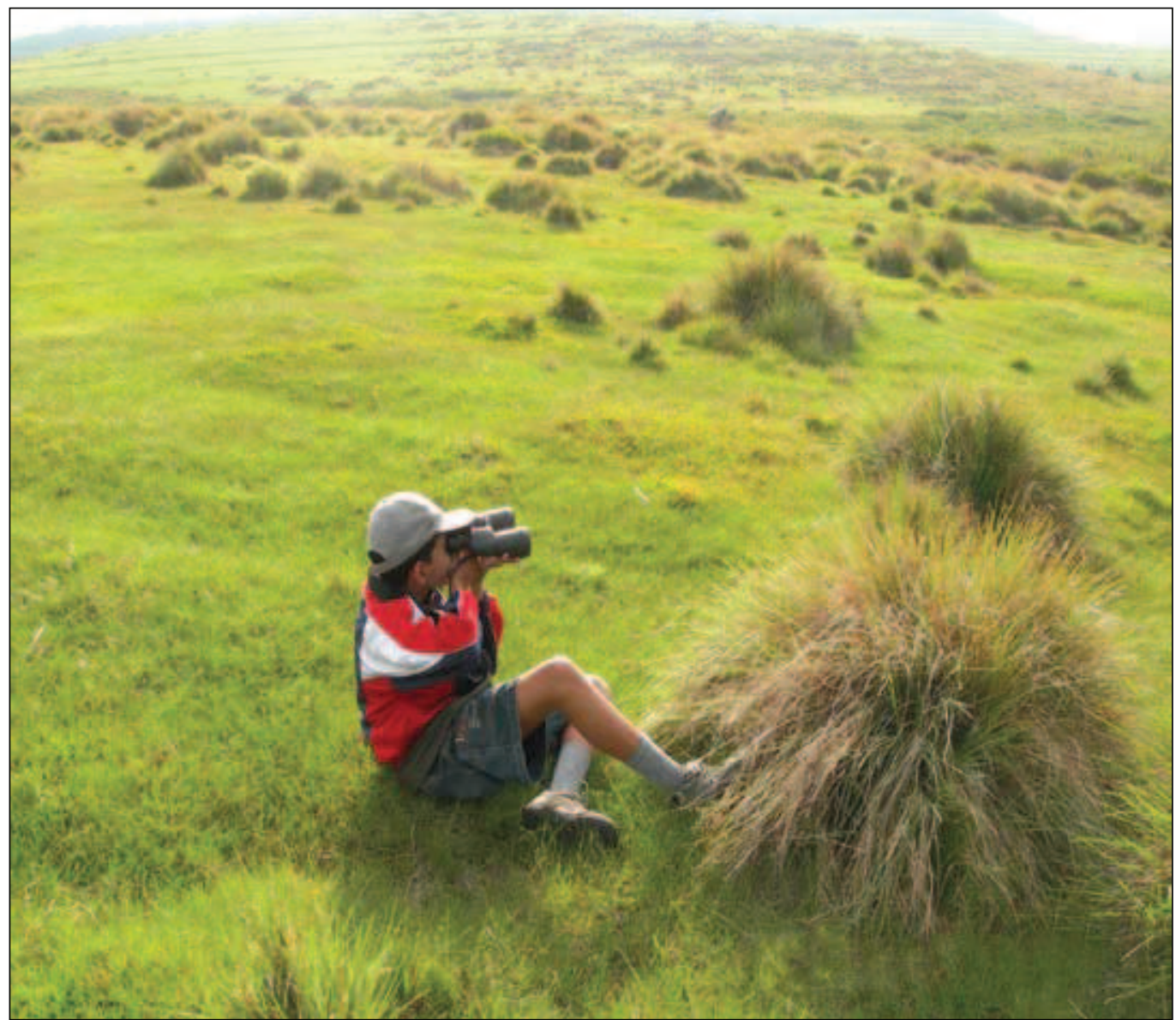

Figure 8: Montane wet patana grasslands cleared and terraced for seed potato farming in the 1970s and later abandoned. The carpet-like grasses introduced along with seed -potatoes are frequently grazed by sambar. Native tussocky grasses 


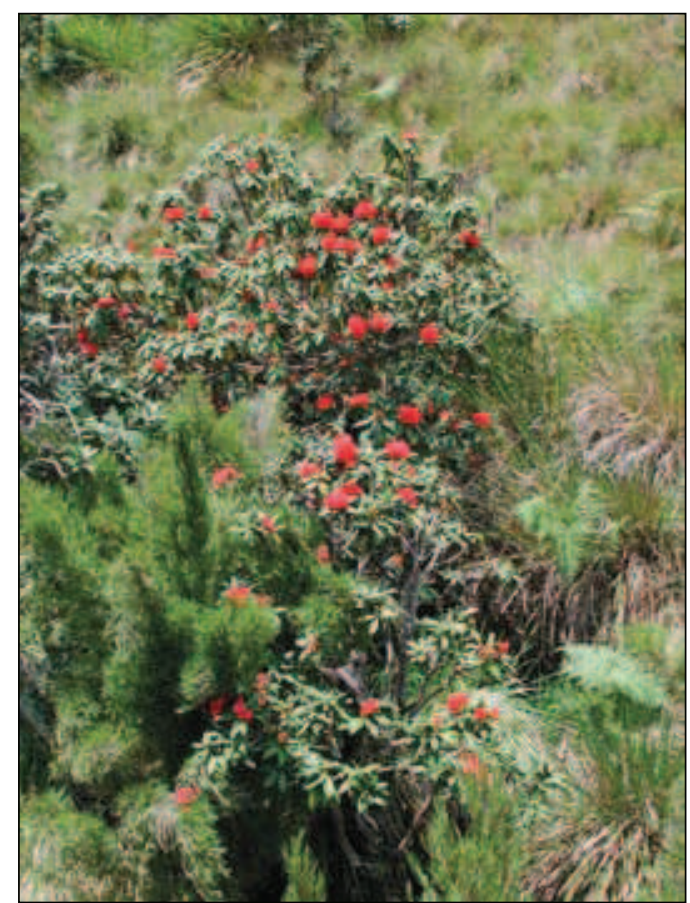

Figure 9: Rhododendron arboreum var. zeylanicum with showy flowers is a characteristic tree more abundant in the grassland than in the neighbouring forest. The dwarf bamboo, Sinarundinaria densifolia and the fern, Pteridium aquilinium are also abundant in the grasslands.

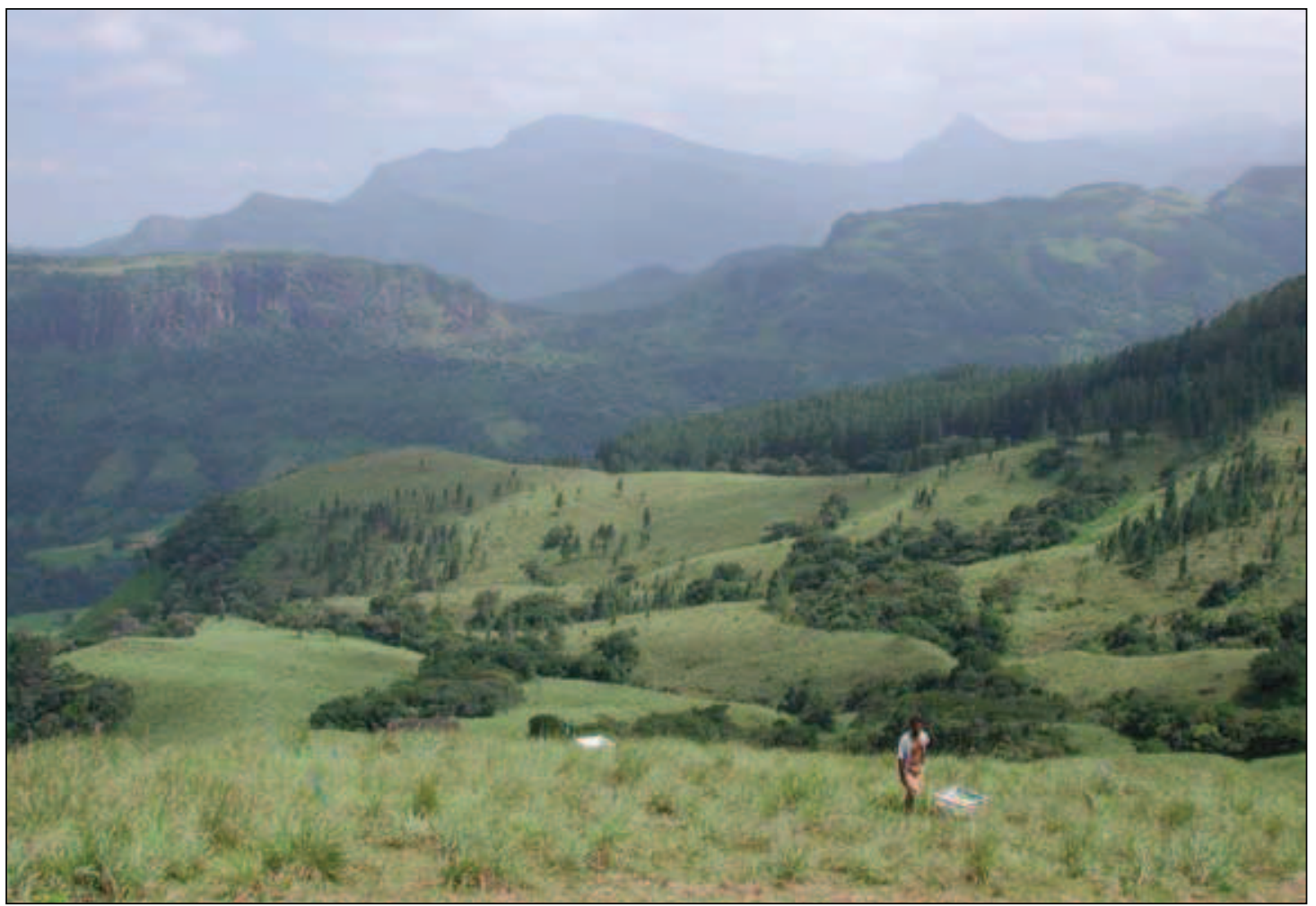

Figure 10 : The dry patana grasslands in the North-eastern Knuckles range has resulted from clearing the forest vegetation for planting tea (Camellia sinensis) and later abandonment. These grasslands in the Central and Uva province have been subsequently planted with exotic tree crops such as Pinus and Eucalyptus spp. 
like Clusia rosea. Ecology of the vegetation in the dry patana grasslands has been studied at Hantana ${ }^{101-103}$

The savannas occur in the intermediate and dry zones, between 300-1000 m elevation. Those on the eastern slopes of the central massif and around the Uva basin are called upland savannas while those in Moneragala and Bibile and in the Gal Oya basin are known as lowland savannas. They resemble a parkland, with scattered, fire-tolerant trees dominated by Careya arborea, Phyllanthus emblica, Terminalia chebula, T. bellirica, all with medicinal properties. The ground layer is dominated by the grass species Cymbopogon polyneuros in association with Themeda triandra at higher elevations and Aristida setacea and Panicum $\mathrm{sp}$. at the lower elevations. Savannas are maintained by anthropogenic fires, mostly to facilitate the collection of fallen fruits of the medicinal species.

These savannas are used as foraging habitats by elephants and other herbivores, especially when there is new growth of the grass species after they have been set on fire. The damanas given below are foraged by these herbivores.

Savanna ecosystems and neighboring habitats have been studied in the VRR sanctuary ${ }^{77,104-107}$ and in the Gal Oya catchment ${ }^{108}$.

Damanas, also known as dry low country parklands or grasslands, occur in the Ampara and Batticoloa districts of the eastern dry zone ${ }^{109}$. They are dominated by the tussock grass Cymbopogon nardus. Other less abundant grass species include Aristida setacea, Imperata cylindrica, Themeda spp., Brachiaria spp., Cyanodon dactylon, Echinocloa colona, Eragrostis sp. and Sporobolus diander. Scattered in the grass are herbaceous (Alisicarpus vaginalis, Desmodium heterophyllum, D. triflorum), woody shrubs (Calotropis gigantea, Cassia auriculata, Lantana camara) and trees (Manilkara hexandra, Pterocarpus marsupium, Acacia leucophloea, Butea monosperma).

Damanas provide fodder to wild elephants and buffaloes. Indeed, these animals are largely responsible for the maintenance of this vegetation, which except for their impact, is likely to contain a higher density of woody species. Leaves of Diospyros melanoxylon, locally known as Kadumberiya, growing in this ecosystem are widely used as wrappers for local cigarettes (beedi).

Talawa grasslands occur in the Haldumulla area, where the topsoil is eroded and truncated to some degree ${ }^{97,109}$. While the tall $(1.5 \mathrm{~m})$ tussock grass Cymbopogon nardus dominates them, other less abundant grasses seen are
Andropogon lividus, Arundinella villosa, Chrysopogon aciculatus and Themeda tremula. The herbs and shrubs scattered among the grass include Desmodium triflorum, Elephantopus scaber, Evolvulus alsinoides, Lantana camara and Psidium guava.

Villus are wetland ecosystems also known as freshwater riverine marshes found in the floodplains of the Mahaweli River in the eastern dry zone and in moist depressions with a perennially high fluctuating water table (Figure 11). Flooding and rain water accumulation suppress any tree growth within the villus but encourage hydrophyllic grasses, sedges and other aquatic plants including some tree species like Terminalia arjuna, Mitragyna parviflora etc., along their perimeters. This ecosystem shows a zonation. The deeper ponding area harbours floating-leaved aquatic plants like Nymphaea nouchali, Nelumbo nucifera, Nymphoides spp., Aponogeton spp. in association with submerged aquatics like Ceratophyllum demursum and Hydrilla verticillata. Hygrorrhiza aristata, a wild relative of rice forms dense buoyant mats while other floating aquatics like Pistia stratoites, Neptunia oleracea and Lemna purpusilla are also found in inundated areas. Near the edge of the villu, a range of grasses, forbs and sedges are found. The characteristic species here are the succulent grasses Iseilema laxum and Paspalidium flavidum.

The villus are important habitats for resident and migrant water birds which include different kinds of plovers, sandpipers, pipits, wag-tails, terns, teels, gulls, geese, ducks, rails, eagles, harriers, cormorants, shags, jacanas etc.

In the villus, both the vegetation and fauna have been surveyed in the Mahaweli flood plains ${ }^{110,111}$.

\section{d) Seasonally flooded forests:}

Seasonally flooded marsh forests are known only from one site, at Waturana, near Bulathsinhala ${ }^{112}$. This ecosystem in the past would have been much more widespread in the low-lying areas of the lowland wet zone, but due to conversion of these habitats to paddy cultivation, the Waturana site is possibly the last remnant of this vegetation. The endemic rare and threatened plant species recorded in this ecosystem include Stemonoporus moonii, Mesua stylosa, Areca concina and Diospyros quaesita; natural populations of the first two of these species are now restricted to this site.

\section{e) Streams, Rivers and Reservoirs:}

Though small in size, Sri Lanka has 103 rivers $(80$ seasonal flowing through the dry zone, 22 perennial 

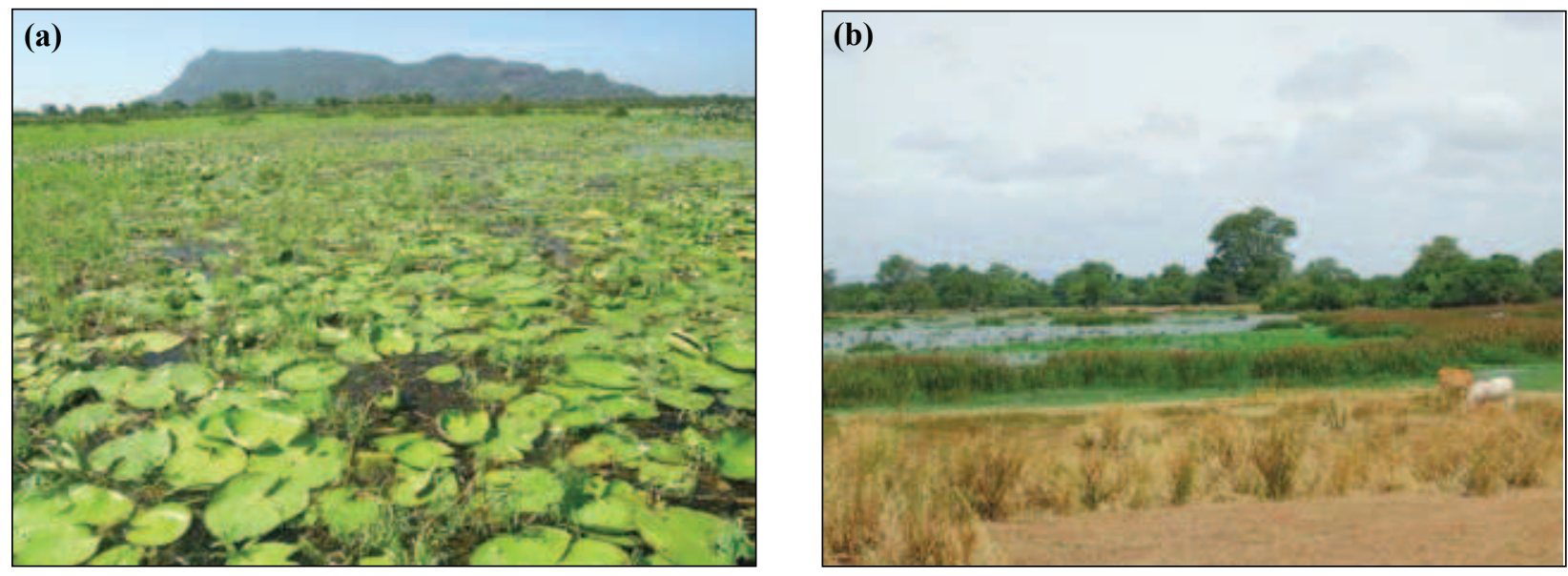

Figure 11 : a) A villu rich in aquatic biota in the Mahaweli flood plains near Dimbulagala rock outcrop in the background. b) There is a clear zonation of the vegetation with floating aquatic plants in the centre and sedges, shrubs and trees along the perimeter of the villu as seen in this picture taken during the dry season.
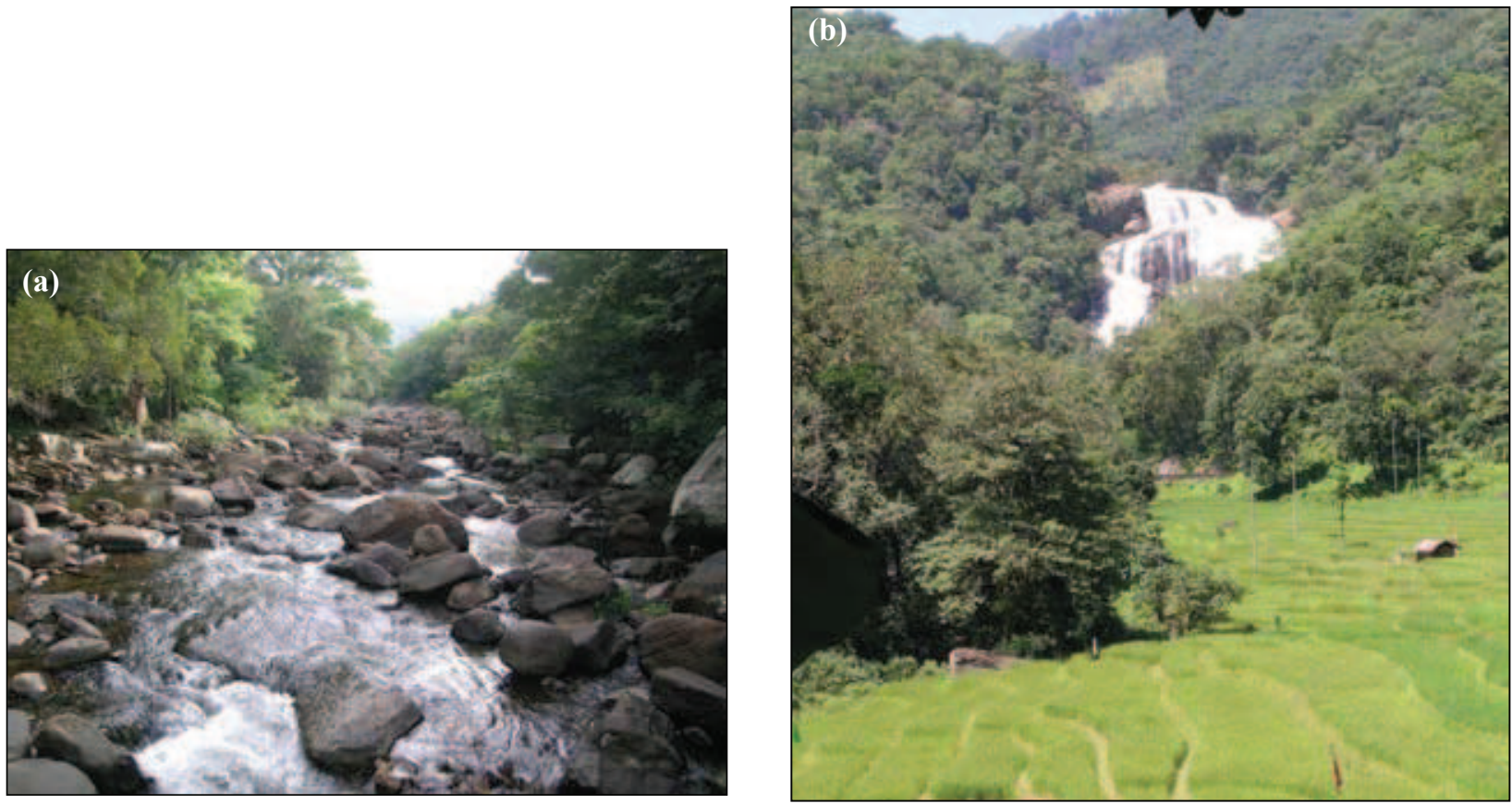

Figure 12 : a) A rocky stream - Theligamu Oya near the North-eastern end and b) a waterfall at the South-eastern end of the Knuckles range. Rapidly flowing fresh-water habitats of this nature harbour a biota unique to them.

traversing the wet and intermediate zones, with the $325 \mathrm{~km}$ long Mahaweli alone running through all three climatic zones) making up a collective length of 4,560 $\mathrm{km}$ (Figure 12).

These rivers, associated streams and waterfalls provide special habitats for certain plant species in the riverine and aquatic ecosystems, some like the Cryptocoryne (all 10 species in Sri Lanka are endemic), Laginandra (7 of the 8 species endemic) and Mapania immersa are endemic to the island. Along the river or stream banks, riverine or gallery forest formations can be observed.

Studies carried out on the meso-fauna in mountain streams at different elevations indicate a rich diversity of species in areas of high currents ${ }^{113,114}$.

Sri Lanka does not have natural lakes, but around 12,000 reservoirs constructed for agricultural purposes 
during the past two millennia, ranging in size from 1-6500 ha, harbour a rich aquatic flora and fauna ${ }^{115,116}$.

\section{Sri Lanka's species diversity: indigenous, endemic and threatened species of fauna and flora}

In the island's flora, the highest species diversity is recorded among the flowering plants, followed in decreasing order by the fungi, bryophytes (mosses and liverworts), freshwater algae and ferns (Table 2). Among animals, the diversity of vertebrates is well known compared to that of invertebrates, where only a few groups have been studied in depth (Table 3).

\section{Endemic species diversity: number and distribution}

Plant Species: The endemic plant species diversity of Sri Lanka comprises 927 or $28 \%$ of flowering plants, of which $60 \%$ are found in the lowland wet zone and 34\% in the montane zone ecosystems of the island (Table 2). Among the ferns, 59 species are endemic to Sri Lanka. Of the island's moss flora, $11 \%$ are endemic ${ }^{59,60}$. Recent revisions on the island's liverworts have not been made and its endemic component is yet to be compiled. Similarly, there is little information on the endemic species among fungi, algae and lichens. In the lichen family Thelotremataceae, as much as $32 \%$ of the species are endemic to the island and all of them are confined to the rain forests ${ }^{125}$.

Animal Species: Among Sri Lanka's 930 vertebrates species, $30 \%$ are endemic to the island. The proportion of endemic species among its amphibians is $\sim 85 \%$, reptiles $\sim 60 \%$ and freshwater fishes $50 \%$. In the invertebrate groups studied in depth, the endemic species component among freshwater crabs is $100 \%$, land snails (83\%), dragonflies (47\%) and butterflies (8\%) (Table 2). Like the endemic plant species, most of the endemic fauna too is confined to the wet-zone natural ecosystems of Sri Lanka.

The increasing human-elephant conflict in the island is also an indication of the poor quality, fragmentation and possibly the inadequate extents of suitable habitat to support Sri Lanka's largest threatened mammal species, the elephant (Elephas maximus), in the protected areas of Sri Lanka.

\section{Threatened, point endemic and extinct species of Sri Lanka}

Plant Species: Currently, Sri Lanka has over 675

Table 3. Numbers of threatened species of selected groups of plants and animals.

\begin{tabular}{lcc}
\hline \multirow{2}{*}{$\begin{array}{c}\text { Plant and animal } \\
\text { groups }\end{array}$} & \multicolumn{2}{c}{$\begin{array}{c}\text { No. and (\%) of nationally threatened } \\
\text { species }\end{array}$} \\
\cline { 2 - 3 } & Endemic & Non-endemic \\
\hline Flora & $412(61)$ & 252 \\
$\quad$ Flowering Plants & $30(53)$ & 60 \\
$\quad$ Ferns & & \\
Vertebrates & $14(88)$ & 27 \\
Mammals & $16(48)$ & 30 \\
Birds & $37(37)$ & 19 \\
Reptiles & $51(57)$ & 1 \\
Amphibians & $20(45)$ & 8 \\
Fishes & & 1 \\
Invertebrates & $32(16)$ & 0 \\
Land snails & $37(73)$ & 0 \\
Freshwater crabs & $20(35)$ & 53 \\
Dragonflies & $13(65)$ & \\
Butterflies &
\end{tabular}

* Percentage calculated on the total number of endemics.

Source: reference no. 117

Table 2. Species diversity among selected flora and fauna and the number of endemics in each group

\begin{tabular}{lclccc}
\hline $\begin{array}{c}\text { Indigenous plant } \\
\text { species }\end{array}$ & $\begin{array}{c}\text { Total no. } \\
\text { of species } \\
\text { (endemics) }\end{array}$ & $\begin{array}{l}\text { Vertebrate } \\
\text { species }\end{array}$ & $\begin{array}{c}\text { Total no. } \\
\text { of species } \\
\text { (endemic) }\end{array}$ & $\begin{array}{c}\text { Invertebrates } \\
\text { species }\end{array}$ & $\begin{array}{c}\text { No. of species } \\
\text { (endemics) }\end{array}$ \\
\hline Flowering plants & $3771(927)$ & Mammals & $91(16)$ & Bees & $148(21)$ \\
Gymnosperms & $1(0)$ & Birds & $482(33)$ & Ants & $181(? ?)$ \\
Ferns \& fern allies & $314(59)$ & Reptiles & $171(101)$ & Butterflies & $243(20)$ \\
Mosses & $561(63)$ & Amphibians & $106+(90+)$ & Spiders & $501(? ?)$ \\
Liverworts & $227(? ?)$ & Fishes & $82(44)$ & Land snails & $246(204)$ \\
Freshwater algae & $560+(?)$ & (Fresh water only) & & Dragon flies & $120(57)$ \\
Fungi & $2260+(?)$ & & & Crabs* & $51(51)$ \\
Lichens & $661(?)$ & & Shrimps* & $23(07)$ \\
\end{tabular}

* Fresh water only.

Sources: reference nos. 59,60,117-124. 


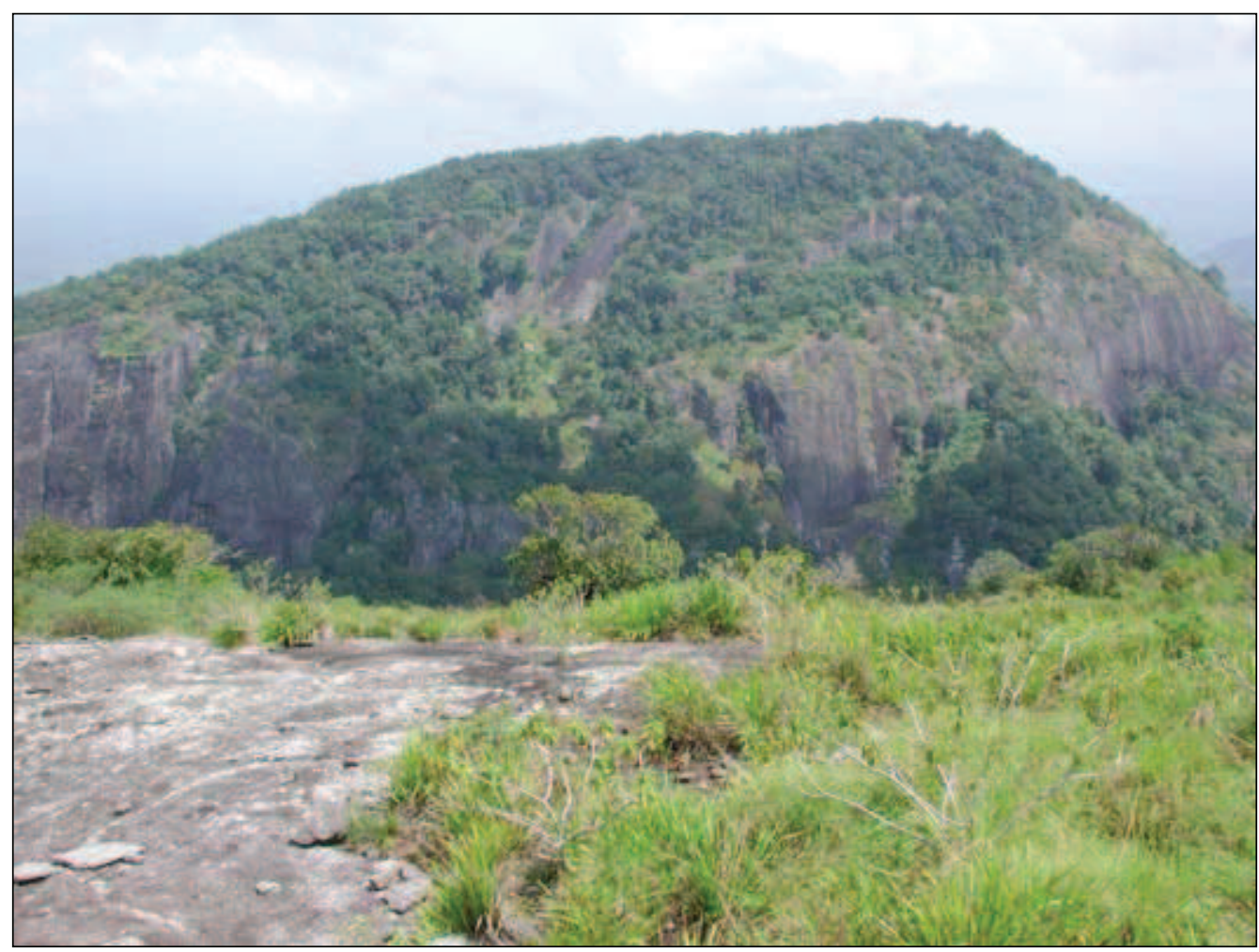

Figure 13 : Rocky out-crops or inselbergs like the Kokagala in the dry zone, harbour plants and animals rarely encountered in the plains below.
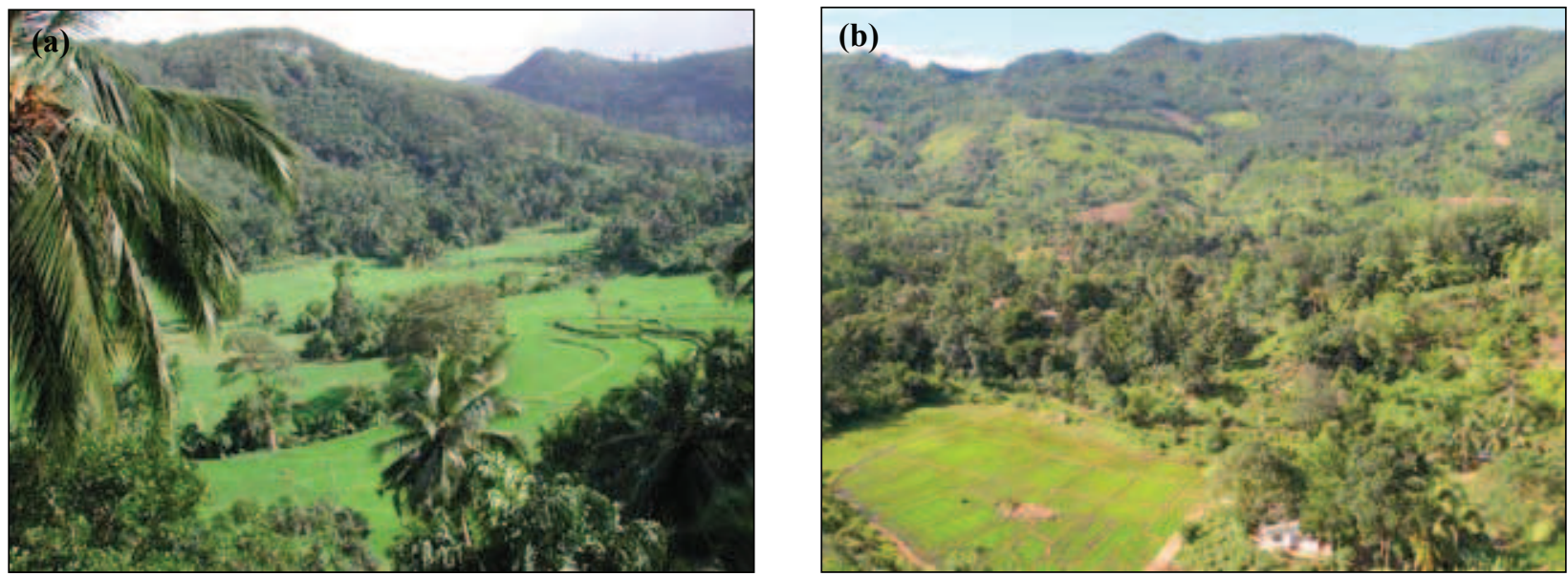

Figure 14 : The paddy fields in the valleys and home gardens often with a stratification analogous to that of the natural forest but substituted with plants of traditional economic value in the lower slopes is a sustainable man-made ecosystem rich in agro-biodiversity in Sri Lanka. The rain forests in the upper slopes were cleared during the period of European colonization in the 19th century for the cultivation of rubber as seen in these photographs. 
Table 4. Status of selected coral reefs in Sri Lanka before and after the El-Nino event of April-May 1998

\begin{tabular}{|c|c|c|c|c|}
\hline Location & Depth (m) & $\begin{array}{l}\text { Pre-bleaching } \\
\text { (\% live coral) }\end{array}$ & $\begin{array}{c}1999-2000 \\
(\% \text { live coral })\end{array}$ & $\begin{array}{r}2001-2002 \\
(\% \text { live coral) }\end{array}$ \\
\hline Bar reef & $0-3$ & $\begin{array}{l}78.5 \\
(1993-1994)\end{array}$ & $\approx 100$ mortality & $\begin{array}{l}\text { Several new colonies } \\
\text { noted; too sparse to } \\
\text { estimate percent }\end{array}$ \\
\hline Bar reef & $7-8$ & - & $\approx 100$ mortality & 14 \\
\hline Kandakuliya & $0-5$ & 22 & $\begin{array}{l}\text { Small colonies } \\
\text { were present }\end{array}$ & $\begin{array}{l}\text { corals smothered } \\
\text { by Halimeda }\end{array}$ \\
\hline Hikkaduwa Nature Res. & $0-4$ & 47.2 & 7 & 12 \\
\hline Hikkaduwa south of NR & $7-13$ & Not estimated & Not measured & 17 \\
\hline Rumassala & $1-5$ & 45 & 19.6 & $\begin{array}{l}\text { Better recovery at } \\
4-5 \mathrm{~m} \text { depth; live } \\
\text { coral not estimated }\end{array}$ \\
\hline Weligama & $0-2$ & 92 & $\begin{array}{l}28 \\
31\end{array}$ & 54 \\
\hline
\end{tabular}

Source: reference no. 142

flowering threatened plant species among the 1099 assessed so far $^{124}$ and 90 fern species assigned a threatened status. Information on the threatened status of species in other plant groups is lacking.

Animal species: Among animals $37-88 \%$ of the endemic species in the vertebrate groups and over 16 $-73 \%$ of species in the invertebrate groups have been assessed as threatened ${ }^{117}$ (Table 3 ).

Sri Lanka's has 108 point (or micro) endemic species, each recorded only from a single site. They include 5 mammal species, 4 agamid lizards, 15 amphibians, 3 freshwater fish and 81 flowering plant species (Appendix 1), almost all confined to the island's wet zone.

There are a large number of species, both plants and animals, not collected during the past century ${ }^{117}$. Many of these could be either extinct or on the brink of extinction. Among the plants, over 30 fern species and 72, (including 42 endemics) of 1099 flowering plants assessed are suspected to be extinct. Among animals suspected extinct are 21 endemic amphibians ${ }^{117}$ and considered extinct in historical times are the gaur and comb duck ${ }^{126}$, and up to 13 species of snakes. Among wild relatives of agricultural crops, those of rice are severely threatened due to habitat loss.

\section{Genetic diversity}

Information on genetic diversity of the natural flora and fauna of Sri Lanka is extremely limited. Studies carried out on the genetic diversity of leopards indicate lower genetic variation in the Sri Lankan populations compared to those of Peninsular Malaysia ${ }^{127,128}$. Molecular analyses have shown that the Sri Lankan leopard is a distinct subspecies, one of ten in the world. Among the SriLanka elephants relatively high levels of differentiation in mtDNA were observed between the northern, mid-latitude and southern regions of the island ${ }^{129}$.

Recent molecular analyses have shown that the direct developing tree frogs of the genus Philautus (Rhacophoridae) represents a large, endemic insular radiation ${ }^{42}$. Molecular phylogenetic studies also have shown that Sri Lankan caecilian fauna are of monophyletic origin, those of the southernwestern lowlands comprising a clade, possibly representing a relatively recent divergence from those of the central highlands ${ }^{130}$.

Among the plants, phylogenetic and population genetic studies have been carried out on some members of Dipterocarpaceae ${ }^{131-134}$ (Shorea and the endemic genus Stemonoporus), Myrtaceae ${ }^{135}$ (Syzygium spp.) and Annonaceae ${ }^{136}$ (Polyalthia spp. and Xylopia championi). The proportion of the total genetic diversity among populations of some of the Dipterocarp species resulting from higher rates of out-crossing is shown to be similar to the average reported in literature for tropical woody species. Lower within-population genetic variation for these species have been reported in logged-over forest fragments, suggesting that forest degradation, fragmentation and habitat size reduction have lead to their genetic erosion ${ }^{131,132}$. 

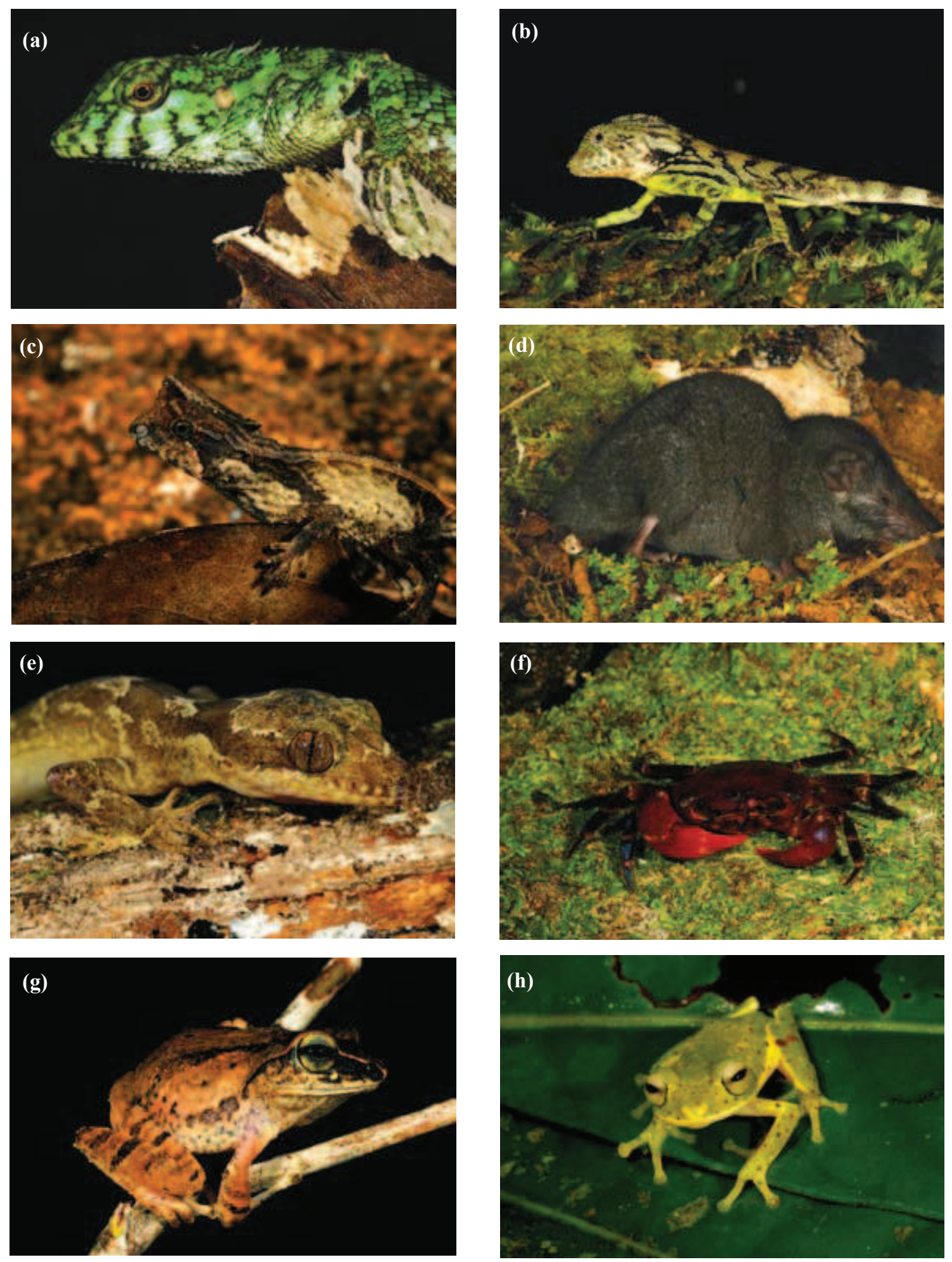

Figure 15 : Sri Lanka is rich in micro-endemic species, such as the ones shown here, which are restricted largely to Morningside, a small forest reserve east of the Sinharaja World Heritage Site. These species were all discovered serendipitously in the course of exploration during the past 15 years, suggesting that significant hitherto unrecorded diversity may exist in other little-explored parts of the island, such as the Peak Wilderness. a) Calotes desilvai; b) Ceratophora erdeleni; c) Ceratophora karu; d) Crocidura hikmiya; e) Cyrtodactylus subsolanus; f) Perbrinckia rosae; g) Philautus frankenbergi; h) Philautus poppiae (Photos courtesy of Madhava Meegaskumbura). 
The genetic diversity of wild relatives, traditional cultivars and land races of crop species are being estimated for both in-situ and ex-situ conservation in both within and outside protected areas, in farmlands and home gardens, gene banks, where appropriate, and characterized primarily through the initiatives of the Departments of Agriculture and Export Agriculture and Plantation Crop Research Institutes ${ }^{137}$. The diversity of crop genetic resources in different agro-ecological regions of the island is quite high. About 645 species of crop wild relatives of Sri Lanka have been catalogued in the National Herbarium at Peradeniya.

\section{Agricultural and medicinal species and their genetic diversity}

Agricultural plant diversity ${ }^{138}$ in the island includes Oryza sativa (rice) with its 2,800 varieties/land races and five wild relatives, 7 coarse-grain species and their traditional cultivars of maize and sorghum; 14 grain legume species; 8 cucurbitaceous, 2 solonaceous and 4 other vegetable (bean, okra, amaranth, chilli) species; 17 root and tuber crop species. The economically useful spices are 8 species of Cinnamon, Elettaria cardamomum, 3 Piper species (with 7 wild relatives), clove, nutmeg, betel nut, vanilla, chilli, and ginger. Others of importance include three major beverage species (tea, coffee and cocoa), sugarcane, kitul plam, arecanut, tamarind, citronella, 3 species of oil crops and 2 fibre crops. The horticultural species include banana with nine cultivars and two wild relatives, citrus, and over 20 other fruit species. The germplasm accessions of these wide range of crops are kept in the seed gene bank and the field gene banks of the Department of Agriculture and also ex situ, in village home gardens ${ }^{137}$.

A total of 1414 species of Sri Lankan plants are considered to be of value to the indigenous (ayurvedic) medicine. Among them 50 are heavily used, 208 commonly used and 79 are threatened. A project has been carried out to lay a foundation for conservation and sustainable use of medicinal plants in Sri Lanka ${ }^{139}$.

\section{Degradation of biodiversity}

Sri Lanka and the Western Ghats of India have been designated as one of the 34 global hotspots of the world ${ }^{1}$ based on the fact that both these regions together harbour at least 1,500 species of vascular plants as endemics and have lost at least $70 \%$ of their original habitat ${ }^{140}$. In addition to habitat loss, most of the remaining habitats of endemics are degraded. In this section, factors responsible for degradation of ecosystem diversity are examined.
Marine and maritime ecosystems: Degradation of coastal ecosystems is due to natural processes (wave action, sea level rise, tsunamis) and human activities such as the mining of beach and river sand, inland coral deposits and shore reefs; construction of groins, harbours, jetties etc.; and improperly sited coastal buildings and removal of coastal vegetation. Destruction of mangrove ecosystems has been attributed to land reclamation, urbanization, pond aquaculture, extraction of firewood and timber, inflow of sediments and pollutants (sewage, industrial effluents) due to poor land use management in inland areas, desalination due to inland irrigation projects; harvesting polychaetes for brood-stock feed; drag-net operations during fishing and conversion to salt pans ${ }^{4,141}$.

Surveys of coral reefs before, during and after the El Niño event of April-May 1998, showed extensive bleaching of corals, up to a depth of $8 \mathrm{~m}$ and drastic reduction of associated fish populations. Recovery has been slow and variable (Table 4) due to overgrowth of calcarious Halimeda sp. and filamentous algal species $^{142,143}$.

The world's fifth-largest quake in a century hit South and Southeast Asia on the $26^{\text {th }}$ of December 2004 unleashing a tsunami that affected Sri Lanka as well. Habitats impacted included sand dunes, salt marshes, mangroves and coastal woodlands and scrublands. The vegetation has been impacted by the force of the wave, inundation by saltwater and sand deposition. Most vegetation types have shown recovery and regeneration with time but how individual species in them have been affected remains to be assessed ${ }^{144}$.

Terrestrial ecosystems: Man's influence on natural vegetation in the island, closely related to the long history of land use in Sri Lanka, falls broadly into six periods (prehistoric, proto-historic, dry zone civilization (500BC-1200AD), late medieval: (1200AD-1500AD), western colonial: (1505 AD -1947AD) and post Independence: (since 1948AD). During each of these periods different parts of the country have been the focus of human activities, that have adversely affected their natural vegetation ${ }^{145}$.

Natural forest ecosystems: The quality of the natural forest ecosystems varies with the forest type. With the exception of relatively small extents in inaccessible areas, most lowland rain forests have been converted to cash-crop agriculture ${ }^{145-147}$, (cinnamon, rubber, coconut and tea) and in recent times selectively logged to supply plywood and hardwood timber (Figure 14). Logging at first was slow, using elephants and hand implements. 
After the 1960s, mechanized logging using chainsaws, skidders, timber jacks, and loaders have led to their rapid degradation ${ }^{148}$ until logging of natural forest was prohibite altogether by an administrative order in 1989 .

Almost all the tropical dry mixed evergreen forests are believed to be secondary in origin and about 500-800 years old (Figure 13). The distribution of numerous tanks (small reservoirs) in Sri Lanka's dry zone suggests that dry zone forests were converted to shifting cultivation and paddy lands at one time or another. Once the reservoirs were abandoned, the forests returned with time, accounting for their secondary origin ${ }^{27,149}$. These forests have also been intensively and selectively logged for their very valuable hardwood timber species such as Ebony (Diospyros ebenum), Palu (Manilkara hexandra), Satinwood (Chloroxylon swietenia), Pannakka (Pleurostylia opposita) and they have also been exploited for fuel wood $^{23}$. In the last few decades, much of this ecosystem has been converted to agriculture following major irrigation schemes.

The lower montane and montane forests, due to their inaccessibility, were less influenced by man during the pre-colonial period. From 1833-1880 (during the British period), about one-thirteenth (4,760 sq. $\mathrm{km}$ ) of the island's land area, mostly the lower montane forests were converted to coffee, cinchona and tea plantations ${ }^{147}$. Timber from these clearings was used both internally and for export charging a royalty. More recently, areas close to the perimeter in the remaining forests have been exploited for fuel wood and for urban and agricultural expansion. Good pristine forests may still be seen in parts of the Peak Wilderness Sanctuary, Hakgala Strict Nature Reserve, Knuckles, Pidurutalagala and Horton Plains. Mining for precious stones also has affected some of these forests. Parts of the Central Highlands, Knuckles range and Rakwana-Deniyaya range have been planted with cardamom after clearing the understorey. Although this practice has been curtailed in recent times, the removal of undergrowth (including of the canopy species), has led to the paucity of juveniles and saplings for regeneration and restoration of the forest structure and composition. The enigmatic die-back of patches of montane forests, very evident in the Horton Plains and Knuckles $^{65,66}$ also lowers the quality of these forests, jeopardizing the biodiversity they harbour (Figure 16). The gaps created by burning and die-back are favourable habitats for the native bracken (Pteridium revolutum); in less exposed gaps the native Strobilanthes spp. and non-native invasive species Aristea eckloni grow abundantly.

It is also ironical that the relative proportion of population increase in the island's wet zone districts, where nearly $90 \%$ of the endemic biodiversity is harboured, is considerably greater compared to that in the dry zone. The proportion of endemic flowering plants in the wet zone is 5.71 per $100 \mathrm{sq} \mathrm{km}$, a figure 50 times greater than that in the dry zone $(0.11$ per $100 \mathrm{sq} \mathrm{km})$. The human population in a comparable area in the wet zone on the other hand is three times greater than that of the dry zone, giving rise to severe human pressure on the aseasonal wet zone forests.

There are numerous non-wood forest products extracted from the natural forest ecosystems of Sri Lanka ${ }^{23,150-155}$. Among them are all 10 species of small and large diameter rattans (Calamus) ${ }^{154}$, which includes 8 endemics, bamboo (Ochlandra stridula, Bambusa bambos), many different species of medicinal plants ${ }^{150}$ such as Bin Kohomba, Weniwelgeta, Kothala Himbutu, Rasa Kinda (Munronia pinnata, Coscinium fenestratum, Salacia reticulata and Tinospora cordifolia, respectively); and food plants such as Kitul, Beraliya, Hal, Wood Apple (Caryota urens, Shorea spp., Vateria copallifera, and Limonia acidissima, respectively) ${ }^{154}$. Other products for domestic use are also extracted, such as roof thatching material from Beru (Agrostistachys intramarginalis), resins from several different species of Shorea, Hal and Kekuna (Canarium zeylanicum) ${ }^{153}$. In species like cane or the medicinal vine veniwelgeta (Coscinium fenestratum), removal of the whole plant drastically reduces the adult population. Thereby fruits are not available for regeneration of the species and precipitating consequent decline.

The past half-century has seen a steady growth in the collection of aquatic fish and plants for the aquarium trade, ornamental plants including orchids and ferns, and wild relatives of agricultural and medicinal species. Among fresh water fish species, $75 \%$ of the indigenous fish, including 21 endemics, had been collected from the wild. However, effective policing and enforcement of export regulations have curtailed this to some extent. In the inland aquatic habitats, the water plants collected illicitly from streams include species of Cryptocoryne (most of which are endemic) and Lagenandra. Arguably the biggest threat, however, to aquatic animal life has been the introduction (both deliberately for fisheries and accidentally by hobbyists) of dozens of exotic species of fish and other aquatic organisms, which are now established in the island's waterways.

\section{Sand removal}

In almost all of Sri Lanka's major rivers sand is mined at an alarmingly high rate for commercial purposes despite augmented regulations to curtail this lucrative activity. 

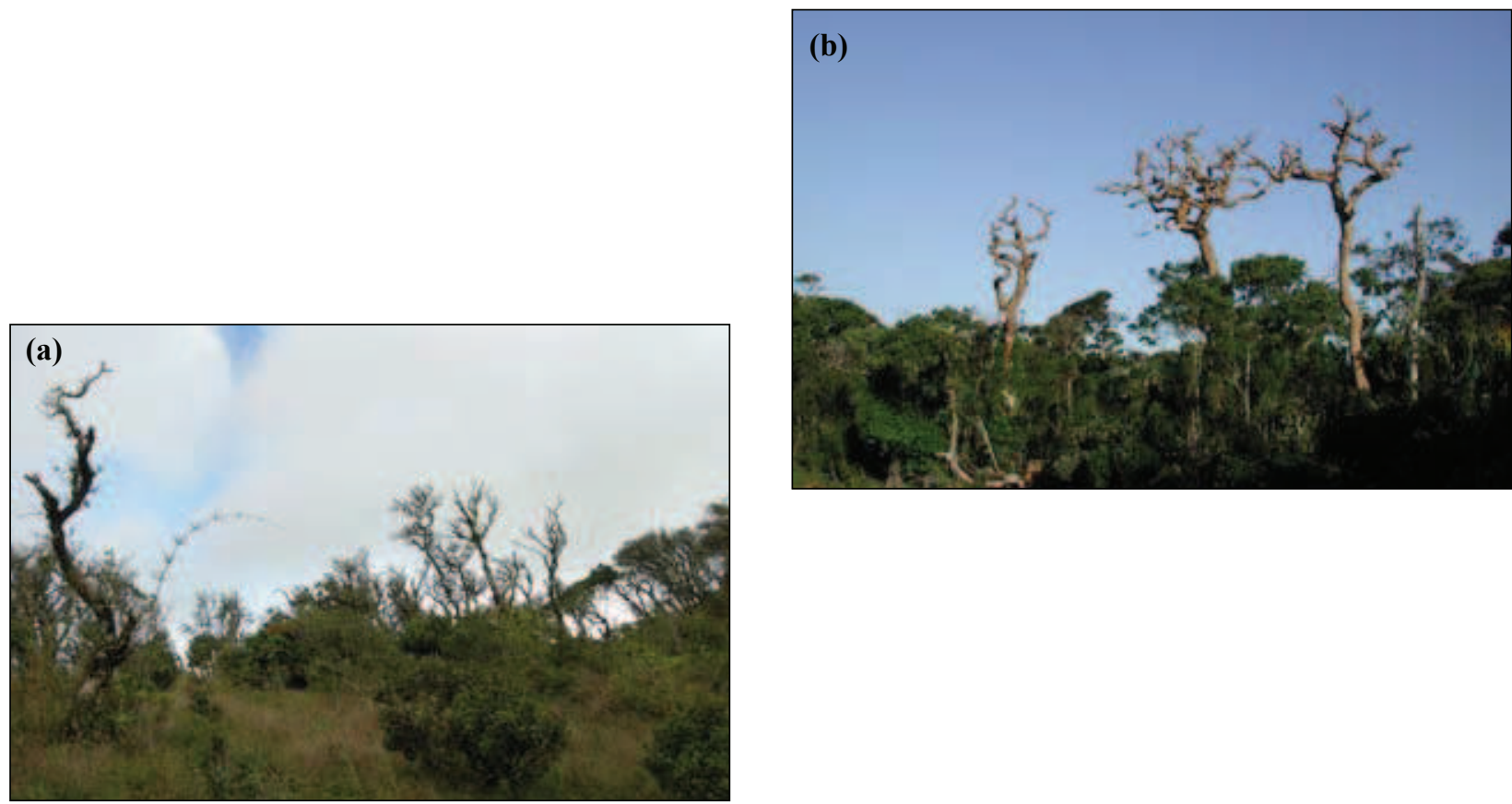

Figure 16: Forest die-back in the a) Knuckles region near the Corbett's Gap area and the undergrowth invaded by a native bamboo species b) Horton Plains National Park.

Table 5: Some invasive species in different natural ecosystems in Sri Lanka

\begin{tabular}{lll}
\hline Ecosystem & Plant species & Animal species \\
\hline Thorn Scrub: Bundala National Park (NP) & $\begin{array}{l}\text { Prosopis juliflora }, \\
\text { Opuntia dillenii }\end{array}$ & Feral buffalo \\
$\begin{array}{c}\text { Savannas: Victoria-Randenigala-Rantambe sanctuary, } \\
\quad \text { Udawalawe National Park. }\end{array}$ & Lantana camara
\end{tabular}

Stream \& river banks: Lowland wet zone

Intermediate zones

Lower montane forests

\section{Moist semi-evergreen forests}

Lowland wet zone rain forests

\section{Montane Zone \\ Wet Patana Grasslands (Horton Plains) \\ Montane forests (Horton Plains)}

Marsh and/or aquatic ecosystems
Dillenia suffruticosa,

Anona glabra

Mimosa pigra

Clusia rosea, Wedelia trilobata

Miconia calvescens

Bambusa bambos

Wedelia trilobata,

Clidemia hirta,

Clerodendrum quadriloculare

(potentially invasive)

\section{Ulex europaeus}

Cestrum aurantiacum,

Ageratina riparia,

Aristea eckloni

Salvinia molesta,

Eichhornia crassipes
Golden apple snail

Common crow

Golden apple snail, Thilapia, Carp 
This not only damages the river bed and pollutes the water, but greatly reduces the amount of sand being carried to the seashore. Consequently, the sea sand washed away due to wave action is not compensated for by the inflow of sand brought in by the rivers leading to severe coastal erosion.

\section{Competition by invasive exotic and indigenous species}

Over the years, a large number of exotic plant and animal species have been introduced, either accidentally or purposefully into Sri Lanka. Some of these species have escaped into natural ecosystems and are now not only growing successfully, but also out-competing the indigenous species in them (Table 5).

In a few other instances some indigenous species in their natural habitats have rapidly expanded their populations, changing their vegetation structure, species composition and even reducing their species richness. Such examples include the bamboo species, Davidsea attenuata (Bata) in parts of the Knuckles range, where it is fast replacing the typical montane tree species and Bambusa bambos (Katu Una) in the VictoriaRandenigala-Rantambe sanctuary and in forests near Bakamuna, out-competing the characteristic species of these tropical moist semi-evergreen forests. Population explosions of both invasive and even indigenous species are indicators of the quality and health of the ecosystems and a good understanding of the long-term dynamics of these systems is imperative if these changes are to be reversed.

\section{Lack of understanding of scientific management}

Scientific management of almost all natural ecosystems in the island at present is still in its inception. Until recently, management of the forest and grassland ecosystems had been largely limited to protection, commercial extraction of timber and control of visitor activities. In most of the inland aquatic habitats, management has been completely ignored. Monitoring the good health of these ecosystems and taking timely measures to counteract any adverse changes have hardly received any attention. This, among other reasons is now posing many problems to Sri Lanka's natural ecosystems. A few may be highlighted here:

In Horton Plains, the sambar (Cervus unicolor) population has increased, possibly in response to the more preferred fodder ${ }^{156-157}$ (Pennisetum clandestinum Kikiyu grass, a naturalized exotic, and $P$. glabrum), which has been inadvertently introduced during the period when part of the area was cultivated for seed potato production. Especially during lactating periods (July-September and November-January) of sambar, the grazing pressure is higher on the carpet grasses, richer in nitrogen than on the bushy tussock grass Chryzopogon nodulibarbis. This, if unchecked may lead to over-browsing of preferred tree species (Cinnamomum ovalifolium, Neolitsea fuscata, Calophyllum walkeri, Eurya japonica, Elaeocarpus subvillosus, Syzygium revolutum and Hedyotis trimenii) in the natural forest.

Continuing forest die-back and the spread of invasive species appear to alter the physiognomy and species composition of the forest landscape. Increasing number of vehicles (hence emissions) and visitors to the reserve entail problems of garbage disposal resulting in the increasing the abundance of the common crow, washing vehicles and discharging pollutants into streams. Predation of the indigenous fauna, by crows, also calls for attention.

Air pollutants, agrochemicals and vehicle exhaust too can adversely affect biodiversity. Lichens are good indicators of air pollution. Their diversity and abundance greatly decrease with pollution, and those species that withstand pollution may increase their populations, outcompeting those that are sensitive to pollution.

Acid rain has also been reported in Horton Plains ${ }^{158}$. The extent to which it contributes to forest die-back and water quality in this ecosystem needs to be investigated.

In Bundala, the increasing population of feral buffalos competing with other herbivores for fodder and freshwater, rapid invasion of the thorn scrub by Prosopis juliflora and Opuntia dillenii at the expense of indigenous species, and changing salinity levels in lagoons due to the Lunugamvehera irrigation project, need to be addressed urgently.

In the Udawalawe National Park and VictoriaRandenigala-Rantembe Sanctuary control of fire has resulted in the invasion of the savannas by Lantana camara followed by other tree species. This groundlayer woody vegetation is less attractive to herbivores compared to the grass cover which it had replaced. In the arid zone, as in Yala, the long dry season is a natural tool to restrain the scrub, unless aggressive weedy species like $P$. julifera and $O$. dilenii take over. Graminivorous birds and other fauna and flora dependent on the grassland habitat would also be affected adversely if timely remedial measures are not taken to maintain ecosystem and habitat diversity in these reserves. 


\section{Pollution}

With the increasing conversion of land to agriculture in Sri Lanka, indiscriminate application of agrochemicals is widespread. Due to the relatively high rainfall, some of these agrochemicals eventually pollute waterways and reservoirs. Industrial waste disposal into waterways also contributes to the poor quality of the island's water resources. Thereby, the richness of the aquatic fauna and flora may be impacted. On many occasions algal blooms and fish kills have been reported in the Kothmale Reservoir and more recently in the Kandy Lake. Indirectly through the effect of pesticides on food chains, the natural biodiversity of these systems may be reduced.

Sediment loads in the water also affect the biodiversity of aquatic systems. Sediment not only blocks out the light, adversely affecting photosynthesis by primary producers in the system, but by reducing visibility in the water impede their foraging and mating activities.
In protected areas where visitor pressure is high, solid waste, particularly polythene waste, is often a problem. Animals have been seen feeding at garbage dumps and consuming polythene in or near protected areas some times with fatal consequences.

\section{Over visitation}

During the last two decades the number of visitors, including school children to wildlife reserves and natural ecosystems have increased many-fold, compounding the problems of solid waste, vehicular traffic and noise pollution, all of which unless carefully managed could lead to degradation of these ecosystems.

Introduction of motorized boats to the Madu Ganga and other aquatic systems have had many adverse effects. Among them are bank erosion due to wave action and oil pollution. The extensive use of kerosene powered vessels and boats using two-stroke engines in the Hikkaduwa Marine Sanctuary has been identified as a major threat to the reef.

Table 6. Important policies, international conventions and legislation related to biodiversity conservation in Sri Lanka.

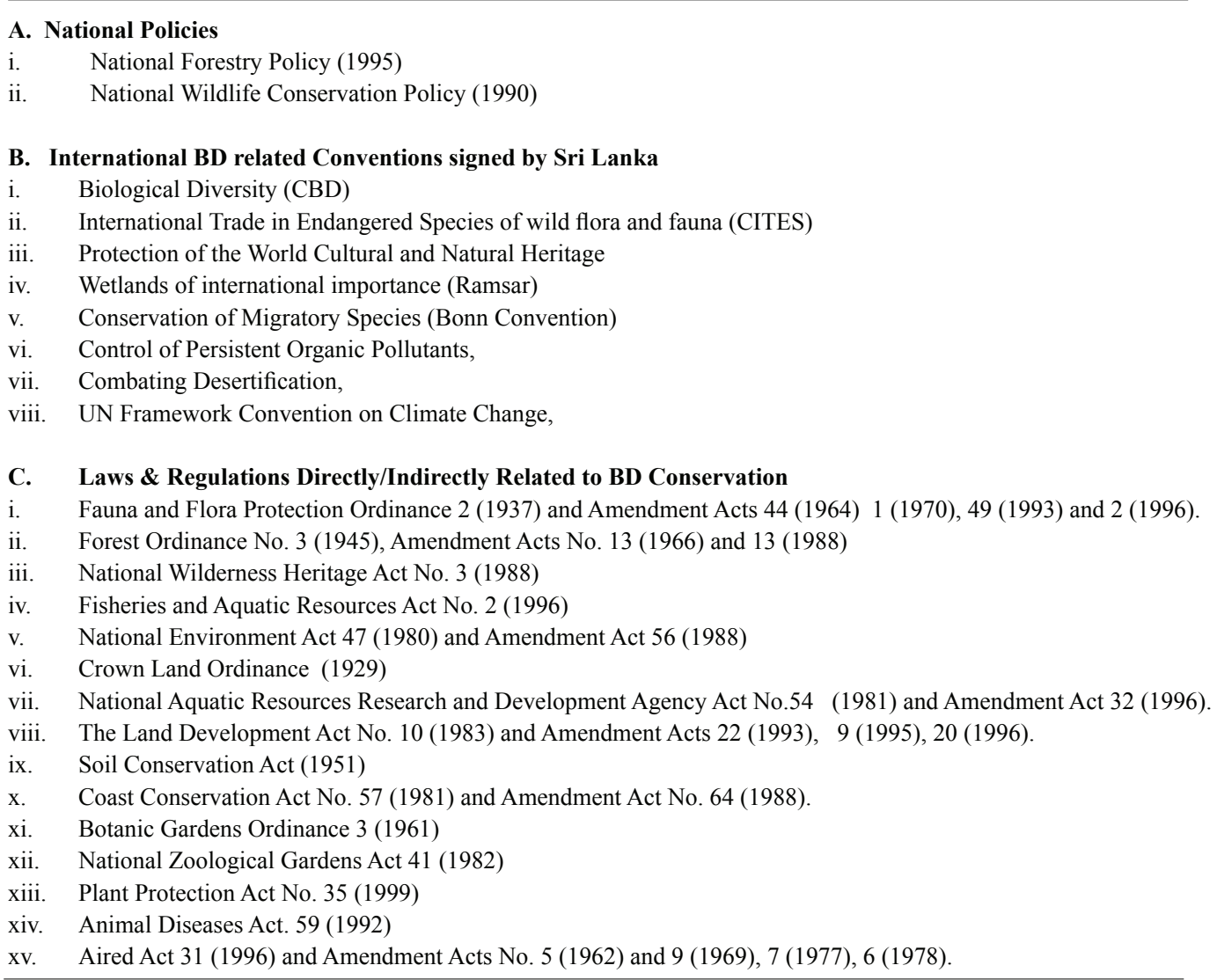




\section{Grasslands}

While parts of the wet patana grasslands have been converted to agriculture (Horton Plains, Nuwara Eliya, Knuckles), some dry patana grasslands in the Uva basin are gradually becoming urbanized, or giving way to, agriculture and exotic mono-specific forest plantations. Many thalawas, damanas and villus have been subject to grazing, and some converted to cash-crop agriculture. These ecosystems have also been subject to fire, a factor essential to maintain them. But recurrent fires at short intervals lead to increased erosion, soil impoverishment and soil moisture stress, all leading to colonization by exotic invasive weeds that aggressively compete with the native species.

\section{Legal and institutional framework for conversation}

Biodiversity conservation policy in Sri Lanka is based on the National Wildlife Policy (2000) and the National Forestry Policy (1995). Several other policy statements too, impinge on the biodiversity sector, including the National Environment Policy and the National Ecotourism Policy. The legal framework for biodiversity conservation rests primarily with the Fauna and Flora Protection Ordinance (FFPO) of 1937 with its later revisions, the Forest Ordinance, National Wilderness Heritage Act, National Environmental Act, Fisheries Ordinance, Coast Conservation Act and several other legislative acts. While some of these acts are overlapping in their mandate, others are, to some extent, in conflict as seen in the case of FFPO and the Fisheries and Aquatic Resources Act in respect of the import and export of fish and other aquatic organisms ${ }^{159}$. The FFPO employs two approaches for species conservation: i) establishment and maintenance of a protected area system wherein all biota within the specified areas are protected from human interference, and ii) listing of protected species in seven different schedules indicating taxonomic groups that are protected (positive listing) or not protected (negative listing $)^{160}$.

Sri Lanka is also a party to several international legal instruments/conventions relating to biodiversity conservation (Table 6). For the export of wild biota, a permit is required unless otherwise stated in regulations. Sri Lanka is bound by the Convention on International Trade in Endangered Species of Wild Fauna and Flora (CITES) which seeks international co-operation in regulating the growing threat from the trade in endangered biota.

Based on the government policies, complying with appropriate international legal instruments and national regulations on biodiversity which are revised from time to time, a number of sectoral master plans, action plans and strategies have been prepared and are being implemented by the relevant government agencies (primarily the Departments of Wildlife Conservation and Forest Conservation) in collaboration with civil society.

The document titled 'Biodiversity Conservation in Sri Lanka: A Framework for Action' ${ }^{159}$ prepared by the Ministry of Forestry and Environment in responding to the article 6 of the Convention on Biological Diversity outlines the national strategies proposed for the conservation, sustainable management and equitable transfer of benefits arising from the biological wealth and its associated knowledge in Sri Lanka. In addition, sector based environmental action programmes including those on forestry, wildlife conservation, agriculture, plantations, fisheries, coastal and marine area management and tourism for the period 2003-2007 have been spelt out ${ }^{161}$.

\section{Biodiversity conservation: some future directions}

From the above review of literature on the biodiversity of Sri Lanka, it is clearly evident that this island is blessed with a rich and diverse biota distributed in a wide array of landscapes and waterscapes. In addition, Sri Lanka also possesses an equally rich religio-cultural heritage spanning over the millennia which had instilled a strong conservation ethic amongst its people. Nonetheless, the degradation of biodiversity has been quite severe particularly during the last two centuries and this trend is still continuing in many different ways in spite of having a comprehensive array of enactments based on sound policies for the conservation of biodiversity. This suggests that mere enactment of regulations without their strict enforcement had not been an effective measure for the conservation of biodiversity and its sustainable management. The regulations to be enforced effectively, there need a strong motivation and commitment towards conservation among all stakeholders which can come effectively through increased awareness of the conservation value through field based conservation education and awareness programmes. The policy and legal framework also fails to recognize that protective measures alone cannot save species threatened with extinction. Despite over 100 species being listed as threatened, there has up to now been very little effort to devise and implement recovery plans for any of these.

At the Millennium Summit of the United Nations held in New York in 2000, eight Millennium Development 
Goals (MDGs) were targeted for achieving during the decade from 2005-2015. Among these, there are at least two viz., achieving universal primary education (goal \#2) and ensuring environmental sustainability (goal \#7) that could be used effectively in biodiversity conservation in the longer term. The Convention on Biological Diversity (CBD) also aims at achieving its Biodiversity Target by reducing the rate of biodiversity loss by 2010. Taking these global proclamations further at the World Summit on Sustainable Development held in Johannesburg in 2002, the governments agreed to reorient national education systems to a vision of sustainability that links economic well-being with respect to cultural diversity and the resources of the planet.

Responding to these challenges, the UNESCO launched its interdisciplinary approaches to help governments and policy makers to achieve these goals through actions aimed at:

i. Sustaining biodiversity at UNESCO World Heritage Sites and Biosphere Reserves,

ii. Linking traditional knowledge to biodiversity management and governance,

iii. Building partnerships to prevent biodiversity loss and degradation, and

iv. Building dialogue to prevent conflicts and share benefits.

The World Network of Biosphere Reserves is developed as a mean to integrate human development with biodiversity conservation and sustainable management of natural resources. As such, they serve as learning platforms and 'out-door laboratories' for testing and demonstrating innovative approaches to reconcile conservation of biodiversity with social and economic development through enhancing cooperation among academic, political, practitioner and other stakeholder communities. The United Nations Decade for Sustainable Development (DESD) for the period from 2005-2014 emphasizes the critical role of education in achieving sustainable development ${ }^{162}$. The 3 rd World
Congress of Biosphere Reserves held in February 2008 at which the Madrid Action Plan (MAP) for the period 2008-2012 was presented, has clearly identified the need for research, training, capacity building and demonstration agendas on conservation and sustainable use of biodiversity, mitigation and adaptation to climate change and socio-economic and cultural well-being of human communities.

In Sri Lanka too, the network of biosphere reserves (both national and international) established in representative ecosystems could be effectively used for meeting the challenges described above. From the primary education levels, appreciation of nature is being instilled in children and the secondary school curriculum now encourages all students to carry out investigative projects. For students with interest in biodiversity conservation, the out-door laboratories of the country's ecosystems are a valuable resource yet to be tapped in a meaningful and innovative manner in meeting our national obligations to the above international goals. Education centers, nature trails and nature interpretation programmes at these sites need to be developed to realize the full potential of these ecosystems as out-door laboratories.

The protected areas network and their surrounding landscape with human habitation in Sri Lanka could be managed in accordance with the MAB concept which intends to fulfil three complementary functions: conservation of biological and cultural diversity, sustainable development and logistic support for education, training, research, and monitoring. To fulfil these functions, the biosphere reserves are organized in three interrelated zones: a legally constituted core area devoted to long-term protection, a buffer zone where activities compatible with the conservation objectives can take place, and an outer transition area where sustainable resource management practices are promoted and developed ${ }^{163}$. This would provide a pragmatic approach for nature conservation in its fullest sense in Sri Lanka as practiced in pre-colonial times while implementing the national conservation strategies and also meeting national obligations to international conventions on biodiversity conservation and environment protection. 
Appendix 1: 'Point endemic' species, each known only from a single site $<100 \mathrm{~km}^{2}$ (for terrestrial sites) or $<5$ linear km (for aquatic sites, streams and rivers). Plant records based on Dassanayake \& Fossberg, 1980-2004. Reptiles other than agamids are excluded for lack of data recorded from Sri Lanka.

Group/Family/Species

BIRDS

\section{AGAMID LIZARDS}

Agamidae

Cnemaspis podihuna
Ceratophora tennentii
Ceratophora karu
Ceratophora erdeleni

AMPHIBIANS

\section{Bufonidae}

Adenomus dasi

\section{Ranidae}

Limnonectes greenii

\section{Microhylidae}

Microhyla karunaratnei

\section{Rhacophoridae}

Philautus macropus

Philautus limbus

Philautus alto

Philautus simba

Philautus fulvus

Philautus caeruleus

Philautus lunatus

Philautus papillosus

Philautus procax

Philautus ocularis

Philautus nemus

\section{FRESHWATER FISH}

Cyprinidae

Puntius bandula

Puntius asoka

Puntius srilankensis
Locality

None

\section{Lahugala \\ Knuckles \\ Morningside \\ Morningside}

Peak Wilderness

Horton Plains

Morningside

Knuckles

Haycock

Horton Plains

Morningside

Knuckles

Peak Wilderness

Handapanella Pl.

Handapanella P1.

Morningside

Morningside

Haycock

Galapitamada

Kitulgala

Pallegama
Group/Family/Species

Locality

\section{FLOWERING PLANTS}

\section{Acanthaceae}

\section{Barleria nutans}

Gymnostachyum thwaitesii

Strobilanthes arnottiana

Strobilanthes caudata

Strobilanthes hypericoides

Strobilanthes nigrescens

Strobilanthes punctata

Strobilanthes thwaitesii

Anacardiaceae

Semecarpus moonii

Annonaceae

Gonicthalamus thomsonii

Apocynaceae

Wrightia flavido-rosea

Aquifoliaceae

Ilex knucklesensis

Araceae

Arisaema constrictum

Cryptocoryne alba

Asclepiadaceae

Brachystelma lankana

Burmanniaceae

Thismia gardneriana

Celastraceae

Clusiaceae

Maytenus fruticosa

Mesua stylosa

Compositae

Anaphalis fruiticosa

Gynura hispida

Cornaceae

Mastixia congylos

Mastixia montana

Mastixia nimalii

\section{Cyperaceae}

Eleocharis lankana

Mapania immersa

Scleria pilosa

Dipterocarpaceae

Hopea brevipetiolaris

Stemonoporus reticulatus
Hantana

Ambagamuwa

Nuwara Eliya

Hantana

Gartmore

Ambagamuwa

Peak Wilderness

Ambagamuwa

Kottawa

Haycock

Doluwakanda

Knuckles

Ramboda

Ingiriya

Laggala

Kuruwita

Nawalapitiya

Kalutara

Peak Wilderness

Horton Plains

Knuckles

Hakgala

Sinharaja

Yakkala

Sinharaja

Kalutara

Doluwakanda

Kanneliya 
Appendix 1. FLOWERING PLANTS continued

Group/Family/Species

\section{Ebenaceae}

Diospyros albiflora

Diospyros atrata

Diospyros koenigii

Diospyros oblongifolia

Diospyros oppositifolia

Ericaulaceae

Eriocaulon subglaucum

Euphorbiaceae.

Glochidion gardneri

Phyllanthus dealbatus

Phyllanthus hakgalensis

Phyllanthus oreophilus

Gentianaceae

Crawfurdia championii

Gesneriaceae

Didymocarpus floccosus

Loranthaceae

Dendrophthoe lonchiphyllus

Helixanthera ensifolia

Macrosolen barlowii

Melastomataceae

Memecylon gracillimum

Memecylon orbiculare

Mimosaceae

Acacia lankaensis

Albizia lankaensis

Monimiaceae

Hortonia ovalifolia

Myrsinaceae

Ardisia wightiana

Myrtaceae

Eugenia glabra

Orchidaceae

Dendrobium maccarthiae

Gastrodia zeylanica

Oberonia claviloba

Oberonia dolabrata
Locality

Morapitiya

Gannoruwa

Gannoruwa

Kanneliya

Haycock

Horton Plains

Peradeniya

Rassagala

Hakgala

Horton Plains

Horton Plains

Dolosbage

Ambagamuwa

Karawita Kanda

Horton Plains

Doluwakanda

Kalubowitiyakanda

Diyaluma

Frotoft Estate

Peak Wilderness

Athweltota

Naunkitaela

Kuruwita

Haycock

Ambagamuwa

Knuckles
Group/Family/Species

Locality

Orchidaceae continued

Oberonia fornicata

Oberonia wallie-silvae

Oberonia weragamaensis

Robiquetia virescens

Taeniophyllum gilimalense

Orobanchaceae

Christisonia albida

Legocia aurantiaca

Piperaceae

Peperomia species

Poaceae

Arundinaria densifolia

Arundinaria scandens

Arundinella thwaitesii

Garnotia fuscata

Garnotia panicoides

Heteropholis nigrescens

Ischaemum polystachyum

Oplismenus thwaitesii

Zenkeria obtusiflora

Podostemaceae

Farmeria metzgerioides

Rhamnaceae

Ziziphus lucida

Rosaceae

Sanguisorba indicum

Rutaceae

Zanthoxylum caudatum

Scrophulariaceae

Adenosma subrepens

Umbelliferae

Peucedanum ceylanicum

Urticaceae

Elatostema walkerae

Zingiberaceae

Amomum acuminatum

Amomum benthamianum

Amomum graminifolium

Amomum nemorale
Knuckles

Rangala

Weragama

Knuckles

Gilimale

Hakgala

Hakgala

Bopathalawa

Horton Plains

Pidurutalagala

Ambagamuwa

Sabaragamuwa

Culloden Estate

Hakgala

Matale

Nalanda

Hakkinda

Erankeliya Eraniya

Peak Wildern.

Eratne

Hewesse

Belihul Oya

Ramboda

Ekneligoda

Reigam Korale

Sinharaja

Hewesse 
Appendix 2: Authority names of plant and animal species referred to in the paper, including tables and Appendix 1.

\section{FLOWERING PLANTS}

\section{Acanthaceae}

Acanthus illicifolius L.

Barleria nutans Nees

Gymnostachyum thwaitesii T. Anders.

Strobilanthes arnottiana Nees

Strobilanthes caudata T. Anders.

Strobilanthes hypericoides J. R. I. Wood

Strobilanthes nigrescens T. Anders.

Strobilanthes punctata Nees

Strobilanthes thwaitesii T. Anders.

\section{Anacardiaceae}

Nothopegia beddomei Gamble

Mangifera zeylanica (Blume) Hook. F.

Semecarpus moonii Thw.

\section{Annonaceae}

Anona glabra L.

Goniothalamus thomsonii Thw.

Xylopia championii Hook. f. \& Thoms.

\section{Apocynaceae}

Wrightia flavido-rosea Trimen

\section{Aquifoliaceae}

Ilex knucklesensis Philcox

\section{Arecaceae}

Areca concinna Thw.

Caryota urens L.

Nypa fruticans Wurmb

\section{Araceae}

Arisaema constrictum Barnes

Cryptocoryne alba de Wit

Pistia stratiotes L.

\section{Asclepediaceae}

Calotropis gigantea (L.) R. Br.

\section{Asclepiadaceae}

Brachystelma lankana Dassanayake \& Jayasuriya

\section{Asteraceae}

Ageratina riparia (Regel) King \& H. Rob.

Anaphalis fruiticosa Hook. f.

Elephantopus scaber L.

Gynura hispida Thw.

Wedelia trilobata (L.) A.S. Hitchc.

\section{Avicenaceae}

Avicennia marina (Forssk.) Vierh.

Avicennia officinalis L.
Bombacaceae

Cullenia rosayroana Kosterm.

Cullenia zeylanica (Gardner)K. Schum.

\section{Burmanniaceae}

Thismia gardneriana Hook. f. ex Thw.

Burseraceae

Canarium zeylanicum (Retz.) Blume

\section{Cactaceae}

Opuntia dillenii (Ker-Gawl.) Haw.

\section{Celastraceae}

Maytenus fruticosa (Thw.) Loes.

Pleurostylia opposita (Wall.) Alston

\section{Hippocrateaceae}

Salacia reticulata Wight

\section{Chenopodiaceae}

Halosarcia indica (Willd.) P. G. Wilson

Salicornia brachiata Roxb.

Sueda maritima (L.) Dumort.

Sueda monoica Forssk. Ex J. F. Gmelin

\section{Clusiaceae}

Calophyllum inophyllum L.

Calophyllum trapezifolium Thw.

Calophyllum walkeri Wight

Clusia rosea Jacq.

Garcinia hermonii Kosterm.

Mesua ferrea L.

Mesua stylosa (Thw.) Kosterm.

\section{Combretaceae}

Lumnitzera racemosa Willd.

Terminalia arjuna (Roxb.) Wight \&Arn. Terminalia bellirica (Gaertn.) Roxb.

Terminalia chebula Retz.

\section{Convolvulaceae}

Evolvulus alsinoides (L.) L.

Ipomea pes-caprae (L.) R. Br.

\section{Cornaceae}

Mastixia congylos Kosterm.

Mastixia montana Kosterm.

Mastixia nimalii Kosterm.

\section{Cyperaceae}

Eleocharis lankana T. Koyama

Mapania immersa (Thw.) Benth. ex Clarke

Scleria pilosa Boeckeler 


\section{Datiscaceae}

Tetrameles nudiflora $\mathrm{R}$. Br.

\section{Dilleniaceae}

Dillenia suffruticosa (Griffith) Martelli

\section{Dipterocapaceae}

Dipterocarpus hispidus Thw.

Dipterocarpus zeylanicus Thw.

Hopea brevipetiolaris (Thw.) Alston

Vateria copallifera (Retz.) Alston

Stemonoporus moonii Thw.

Shorea gardneri (Thw.) Ashton

Shorea trapezifolia (Thw.) Ashton

Stemonoporus reticulatus Thw.

\section{Ebenaceae}

Diospyros melanoxylon Roxb.

Diospyros albiflora Alston

Diospyros atrata Alston

Diospyros ebenum Koenig.

Diospyros koenigii Kosterm.

Diospyros oblongifolia (Thw.) Kosterm.

Diospyros oppositifolia Thw.

Diospyros quaesita Thw.

\section{Elaeocapaceae}

Elaeocarpus subvillosus Arn.

\section{Ericaceae}

Rhododendron arboreum ssp. zeylanicum (Booth)

Tagg

\section{Ericaulaceae}

Eriocaulon subglaucum Ruhland

\section{Euphorbiaceae}

Agrostistachys intramarginalis Philcox

Dimorphocalyx glabellus Thw.

Drypetes sepiaria (Wight \& Arn.) Pax \& Hoffm.

Glochidion gardneri Thw.

Phyllanthus dealbatus Alston

\section{Euphorbiaceae Contd.}

Phyllanthus emblica L.

Phyllanthus hakgalensis Thw. ex Trimen

Phyllanthus oreophilus Muell. Arg.

Phyllanthus polyphyllus Willd.

\section{Fabaceae}

Acacia lankaensis Kosterm.

Acacia leucophloea (Roxb.) Willd.

Acacia planifrons Wight \& Arn.

Albizia lankaensis Kosterm.

Alisicarpus vaginalis (L.) DC.

Bauhinia racemosa Lam.

Butea monosperma (Lam.) Taub.

Cassia auriculata L.
Desmodium heterophyllum (Willd.) DC.

Desmodium triflorum (L.) DC.

Dichrostachys cinerea (L.) Wight \& Arn.

Mimosa pigra L.

Neptunia oleracea Lour.

Pericopsis mooniana (Thw.) Thw.

Prosopis juliflora (Sw.)DC.

Pterocarpus marsupium Roxb.

Ulex europaeus L.

\section{Gentianaceae}

Crawfurdia championii (Gardner)Trimen

Exacum walkeri Arn.

\section{Gesneriaceae}

Didymocarpus floccosus Thw.

\section{Hydrocharitaceae}

Enhalus acoroides (L. f.) Royle Hydrilla verticillata (1. f.) Royle

Thalassia hemprichii (Ehrenb.) Asch.

\section{Iridaceae}

Aristea eckloni Baker

\section{Lauraceae}

Actinodaphne speciosa Nees

Cinnamomum ovalifolium Wight

Cryptocarya wightiana Thw.

Litsea ovalifolia (Wight) Trimen

Neolitsea fuscata (Thw.) Alston

\section{Lecythidaceae}

Barringtonia asiatica (L.) Kurz

Careya arborea Roxb.

\section{Lemnaceae}

Lemna purpusilla Torrey

\section{Loranthaceae}

Dendrophthoe lonchiphyllus (Thw.) Danser.

Helixanthera ensifolia (Thw.) Danser.

Macrosolen barlowii Wiens

\section{Malvaceae}

Thespesia populnea (L.) Sol.ex Correa

\section{Melastomataceae}

Clidemia hirta (L.) D. Don

Memecylon gracillimum Alston

\section{Melastomataceae}

Memecylon orbiculare Thw.

Miconia calvescens DC.

Osbeckia octandra (L.) DC.

\section{Meliaceae}

Munronia pinnata (Wall.) Theob. 


\section{Menispermaceae}

Coscinium fenestratum (Gaertn.) Colebr.

Tinospora cordifolia (Willd.) Hook. f. \& Thoms.

\section{Monimiaceae}

Hortonia ovalifolia Wight

\section{Moraceae}

Antiaris toxicaria Leschen.

Artocarpus gomezianus Wall. Ex Trecul

\section{Myristicaceae}

Myristica dactyloides Gaertn.

\section{Myrsinaceae}

Ardisia wightiana (Wall. Ex A. DC.) Mez.

\section{Myrtaceae}

Eugenia bracteata Roxb.

Eugenia glabra Alston

Psidium guajava L.

Syzygium revolutum Walp.

Syzygium rotundifolium Arn.

Syzygium umbrosum Thw.

\section{Nelumbonaceae}

Nelumbo nucifera Gaertn.

\section{Nymphaeaceae}

Nymphaea nouchali Burm. f.

\section{Orchidaceae}

Dendrobium maccarthiae Thw. Gastrodia zeylanica Schlechter Oberonia claviloba Jayaweera

Oberonia dolabrata Jayaweera

Oberonia fornicata Jayaweera

Oberonia wallie-silvae Jayaweera

Oberonia weragamaensis Jayaweera

Robiquetia virescens (Gard. ex Lindley) Jayaweera

Satyrium nepalense D. Don

Taeniophyllum gilimalense Jayaweera

\section{Orobanchaceae}

Christisonia albida Thw. ex Benth.

Legocia aurantiaca (Wight) Livera

Poaceae

Themeda triandra Forssk.

Andropogon lividus Thw.

Bamboosa bambos (L.) Voss ex Vilmorin

Sinarundinaria densifolia (Munro). Chao \& Renvoize

Aristida setacea Retz.

Arundinaria scandens Soderstrom \& Ellis

Arundinella thwaitesii Hook. f.

Arundinella villosa Arn. ex Steud.

Chrysopogon aciculatus (Retz.) Trin.

Chrysopogon nodulibarbis (Steud.) Henrard

Cyanodon dactylon (L.) Pers.

Cymbopogon nardus (L.) Rendle
Cymbopogon polyneuros (Steud.) Stapf.

Davidsea attenuata(Thw.) Soderstrom \& Ellis

Echinocloa colona (L.) Link

Garnotia fuscata Thw.

Garnotia panicoides Trimen

Garnotia exaristata Gould

Heteropholis nigrescens (Thw.) C. E. Hub.

Hygrorrhiza aristata (Retz.) Nees.

Imperata cylindrica (L.) Rausch.

Ischaemum polystachyumJ. \& C. Presl.

Iseilema laxum Hack.

Ochlandra stridula Moon ex Thw.

Oplismenus thwaitesii Hook.f.

Oryza sativa L.

Panicum maximum Jacq.

Paspalidium flavidum (Retz.) A. Camus

Pennisetum clandestinum Hochst. Ex Chivo.

Pennisetum glabrum Steud.

Spinifex littoreus (Burm. f. ) Merr.

Sporobolus diander (Retz.) P. Beauv.

Themeda tremula (Steud.) Hack.

Zenkeria obtusiflora (Thw.) Benth.

\section{Podostemaceae}

Farmeria metzgerioides (Trimen) Willis ex.

\section{Pontideriaceae}

Hook. f.

Eichhornia crassipes (Mart.) Solms-Laub.

\section{Rhamnaceae}

Ziziphus oenoplia (L.) Miller

Ziziphus lucida Moon ex Thw.

\section{Rhizophoraceae}

Bruguiera gymnorhiza (L.) Savigny

Bruguiera sexangula (Lour.) Poir.

Ceriops tagel (Perr.) C. B. Rob.

Rhizophora apiculata Blume

Rhizophora mucronata Poir.

\section{Rosaceae}

Sanguisorba indicum (Gardner) Tirv.

\section{Rubiaceae}

Mitragyna parviflora (Roxb.) Korth.

Hedyotis trimenii Deb \& Dutta

\section{Rutaceae}

Chloroxylon swietenia D.C.

Limonia acidissima $\mathrm{L}$.

Zanthoxylum caudatum Alston

\section{Salvadoraceae}

Salvadora persica $\mathrm{L}$.

\section{Sapindaceae}

Dimocarpus longan Lour.

Felicium decipiens (Wight \& Arn.) Thw.

Schleichera oleosa (Lour.) Oken 


\section{Sapotaceae}

Manilkara hexandra (Roxb.) Daubard

\section{Scrophulariaceae}

Adenosma subrepens (Thw.) Benth.

Pedicularis zeylanica Benth.

\section{Solonaceae}

Cestrum aurantiacum Lindley

\section{Sonneratiaceae}

Sonneratia alba J. Sm.

Sonneratia caseolaris (L.) Engl.

\section{Sterculiaceae}

Pterospermum suberifolium (L.) Willd.

Pterygota thwaitesii (Masters) Alston

\section{Symplocaceae}

Symplocos cochinchinensis (Lour.) S. Moore

Theaceae

Eurya chinensis R. Br.

Thymelaeaceae

Wikstroemia indica (L.) C. A. Meyer

\section{Ulmaceae}

Gironniera parvifolia Planch.

\section{Apiaceae}

Peucedanum ceylanicum Gardner

\section{Urticaceae}

Elatostema walkerae Hook. f.

Vacciniaceae

Gaultheria leschenaultii DC.

\section{Verbenaceae}

Clerodendrum quadriloculare (Blanco) Merr. Lantana camara L.

\section{Zingiberaceae}

Amomum acuminatum Thw. Amomum benthamianum Trimen Amomum graminifolium Thw. Amomum nemorale (Thw.) Trimen Elettaria cardamomum (L.) Maton

\section{PTERIDOPHYTES}

Ceratophyllaceae

Ceratophyllum demursum $\mathrm{L}$.

\section{Dennstaedtiaceae}

Pteridium revolutum (Blume) Nakai

\section{Salviniaceae}

Salvinia molesta D.S. Mitch.

\section{FAUNA}

\section{MAMMALS}

Elephantidae

Elephas maximus Linnaeus, 1758

\section{AGAMID LIZARDS}

Agamidae

Cophotis ceylanica Peters, 1861

Calotes nigrilabris Peters, 1860

Cnemaspis podihuna Deraniyagala, 1944

Ceratophora tennentii Gunther \& Gray 1861

Ceratophora karu Pethiyagoda \& Manamendra-

Arachchi, 1998

Ceratophora erdeleni Pethiyagoda \& Manamendra-

Arachchi, 1998

\section{SEA TURTLES}

Cheloniidae

Caretta caretta (Linnaeus, 1758)

Chelonia mydas (Linnaeus, 1758)

Eretmochelys imbricata (Linnaeus, 1766)

Lepidochelys olivacea (Eschscholtz, 1829)

\section{Dermochelyidae}

Dermochelys coriacea (Vandelli, 1761)

\section{AMPHIBIANS}

\section{Bufonidae}

Adenomus dasi Manamendra-Arachchi \& Pethiyagoda, 1998

\section{Ranidae}

Fejervaryia greenii (Boulenger, 1904)

Limnonectes greenii (Boulenger, 1904)

\section{Microhylidae}

Microhyla karunaratnei Fernando \& Siriwardhane, 1996 Microhyla zeylanica Parker \& Hill, 1949

\section{Rhacophoridae}

Philautus alto Manamendra-Arachchi \& Pethiyagoda, 2005

Philautus caeruleus Manamendra-Arachchi \&

Pethiyagoda, 2005

Philautus fulvus Manamendra-Arachchi \& Pethiyagoda, 2005

Philautus limbus Manamendra-Arachchi \& Pethiyagoda, 2005

Philautus lunatus Manamendra-Arachchi \&

Pethiyagoda, 2005

Philautus macropus (Gunther, 1869)

Philautus microtympanum (Gunther, 1859)

Philautus nemus Manamendra-Arachchi \& Pethiyagoda, 2005

Philautus ocularis Manamendra-Arachchi \&

Pethiyagoda, 2005

Philautus papillosus Manamendra-Arachchi \& 
Pethiyagoda, 2005

Philautus poppiae Meegaskumbura \& ManamendraArachchi, 2005

Philautus procax Manamendra-Arachchi \& Pethiyagoda, 2005

Philautus schmarda (Kelaart, 1854)

Philautus simba Manamendra-Arachchi \& Pethiyagoda, 2005

Philautus steineri Meegaskumbura \& Manamendra-

Arachchi, 2005

Philautus variabilis (Gunther, 1859)

Polypedates eques Gunther, 1858

\section{FRESH WATER FISHES}

\section{Cyprinidae}

Puntius bandula Kottelat \& Pethiyagoda, 1991

Puntius asoka Kottelat \& Pethiyagoda, 1989

Puntius srilankensis (Senanayake 1985)

\section{FRESH WATER SHRIMPS AND CRABS}

Atyidae

Lancaris kumariae (de Silva, 1990)

Lancaris sinhalensis (Ortmann, 1894)

\section{Parathelphusidae}

Ceylonthelphusa sorror (Zehntner, 1894)

Ceylonthelphusa diva Bahir \& Ng, 2005

Ceylonthelphusa savitriae Bahir \& Ng, 2005

Perbrinckia glabra Ng, 1995

Perbrinckia gabadagei Bahir \& Ng, 2005

Perbrinckia punctata Ng, 1995

Perbrinckia rosae Bahir \& Ng, 2005

\author{
ANTS \\ Aneuretinae \\ Aneuretus simoni (Emery, 1893)
}

\section{References}

1. Mittermeier R.A., Gil P.R., Hoffmann M., Pilgrim J., Brooks T., Goettsch Mittermeier C., Lamoreux J. \& Da Fonseca G.A.B. (2004). Hotspots Revisited: Earth's Biologically Richest and Most Endangered Terrestrial Ecoregions. pp. 392. Cemex, Mexico.

2. Kotagama S.W. \& Bambaradeniya C.N.B. (2006). An Overview of the Wetlands of Sri Lanka and Their Conservation Significance. pp. 11. IUCN Sri Lanka and the Central Environmental Authority, Colombo,

3. Anonymous (2002). State of the Environment in Sri Lanka. A National Report Prepared for the South Asian Association for Regional Cooperation. pp. 245. Ministry of Environment and Natural Resources, Battaramulla.

4. Anonymous (1990). Coastal Zone Management Plan. pp. 81. Coast Conservation Department, Colombo.

5. Abeywickrama B. A. \& Arulgnanum. P. (1993). The Coastal Plants of Sri Lanka Part I (Salt Marsh Plants) pp. 19. National Science Council of Sri Lanka, Colombo 7.

6. Pemadasa M. A., Balasubramaniam S., Wijewansa H. G. \& Amarasinghe L. (1979). The ecology of a salt marsh in Sri Lanka. Journal of Ecology 67(1): 41 - 63.

7. Arulchelvam K. (1968). Mangroves. The Ceylon Forester 8 (3 \& 4): 52-92.

8. Ranawana K. B. (1994). Ecology of lagoon fringing and riverine mangroves of the Northwest, West and South Coasts of Sri Lanka. M. Phil. Thesis, University of Peradeniya, Peradeniya.

9. Bambaradeniya C. N. B., Ekanayake S. P., Kekulandela L. D. C. B., Samarawickrama V. A. P., Ratnayake N. D. \& Fernando R. H. S. S. (2002). An assessment of the Status of Biodiversity in the Muthurajawela Wetland Sanctuary. pp. 48. Occassional Papers of IUCN Sri Lanka, No. 3.

10. Jayatissa L.P., Dahdouh-Guebas F. \& Koedam N. (2002). A review of the floristic composition and distribution of mangroves in Sri Lanka. Botanical Journal of the Linnean Society 138: 29 - 43.

11. Amerasinghe M. D. (1989). Structural and functional properties of mangrove ecosystems in Puttalam Lagoon and Dutch Bay, Sri Lanka. M. Phil. Thesis, University of Peradeniya, Peradeniya.

12. De Silva K.H. G. M. \& Balasubramaniam, S.(1984/1985). Some ecological aspects of the mangrroves on the west coast of Sri Lanka. Ceylon Journal of Science (Biological Sciences). 17/18: 22-41.

13. Pinto L. (1978). Some ecological principles of selected mangrove islets in Negombo Lagoon (Sri Lanka). M. Phil. Thesis, University of Colombo, Colombo 03.

14. Kugathassan K. S. (1969). Mangrove vegetation of the lagoon. A guide to the study of distribution, identification and characterization of the lagoon in particular and common species, in general. Hydrobiological survey of the Thondamannaru Lagoon. Bulletin No. 7 pp. 23. Northern Province Teachers Association, Sri Lanka.

15. de Silva K. H. G. M. \& de Silva P. K. (1998). Status, diversity and conservation of the mangrove forests of Sri Lanka. Journal of South Asian Natural History 3 (1): $79-102$. 
16. Pinto L. (1980). Some ecological aspects of a population of mangrove crabs occurring within the islets of Negombo Lagoon (Sri Lanka). Proceedings of the Asian Symposium on Mangrove Environment, Research and Management, August 25-29, Kuala Lumpur.

17. Pinto L. \& Wignarajah S. (1980). Some ecological aspects of the edible oyster Crassostrea cuculata (Born) occuring in association with the mangroves in the Negombo Lagoon, Sri Lanka. Hydrobiologia 69: 11 - 20.

18. Pinto L. \& Punchihewa N. N. (2004). Utilisation of mangroves and seagrasses by fishes in the Negombo Estuary, Sri Lanka. Marine Biology 126(2): 333 - 345.

19. Samarakoon J. \& van Zon H. (1991). Environmental Profile of Muthurajawela and Negombo Lagoon. Greater Colombo Economic Commission and Euroconsult, The Netherlands.

20. Amerasinghe U. S., Amerasinghe M. D. \& Nissanka C. (2002). Investigation of the Negombo Estuary (Sri Lanka) brush park fishery, with an emphasis on community-based management. Fisheries Management and Ecology 9 (1): 41-56.

21. De Silva A. (2006). An annotated bibliography of publications on marine turtles of Sri Lanka. Indian Ocean Turtle Newsletter 3: 12-26.

22. Ashton P.S. \& Gunatilleke C.V.S. (1987). New light on the plant geography of Ceylon I: Historical plant geography. Journal of Biogeography 14: 249-285.

23. Anonymous (1995). Sri Lanka Forestry Sector Master Plan. pp. 511. Forestry Planning Unit, Ministry of Agriculture, Battaramulla.

24. Gunatilleke I.A.U.N. \& Gunatilleke C.V.S. (1984). Distribution of endemics in the tree flora of a lowland hill forest in Sri Lanka. Biological Conservation 28: 275-285.

25. Gunatilleke C.V.S. \& Ashton P.S. (1987). New light on the plant geography of Ceylon II: The ecological biogeography of the lowland endemic tree flora. Journal of Biogeography 14: 295-327.

26. Gunatilleke C.V.S. \& Gunatilleke I.A.U.N. (1985). Phytosociology of Sinharaja: a contribution to rain forest conservation in Sri Lanka. Biological Conservation 31:21-40.

27. Peeris C.V.S. (1975). The ecology of the endemic tree species of Sri Lanka in relation to their conservation. Ph.D. Thesis, University of Aberdeen, UK.

28. Singhakumara B.M.P. (1995). Ecological Assessment of the Kanneliya-Dediyagala-Nakiyadeniya (KDN) Forest Complex. pp. 70, Department of Forestry and Environmental Science, University of Sri Jayewardenepura, Gangodawila, Nugegoda.

29. Manage U. (1999). Structure and floristic survey of the Delwala Proposed Reserve with emphasis on altitudinal variation. B.Sc. Research Report, University of Colombo, Colombo 03.

30. Anonymous (1997). Designing an Optimum Protected Areas System for Sri Lanka's Natural Forests, Vol. 1, pp. 201. The World Conservation Union, World Conservation Monitoring Centre and Food and Agriculture
Organization of the United Nations.

31. Gunatilleke C.V.S., Gunatilleke I.A.U.N., Ethugala A. U. K. \& Esufali S. (2004). Ecology of Sinharaja Rain Forest and the Forest Dynamics Plot in Sri Lanka's Natural World Heritage Site. pp. 221, Wildlife Heritage Trust Publications (Pvt.) Ltd., Colombo.

32. Wijesinghe M.R. (2006). Ecological traits of endemic small mammals in rainforests of Sri Lanka and their implications for conservation. In: Fauna of Sri Lanka: Status of Taxonomy Research and Conservation. (Ed. C.N.B. Bambaradeniya) pp. 232-234, The World Conservation Union, Colombo and Government of Sri Lanka.

33. Kotagama S.W. \& Goodale E. (2004). The composition and spatial organisation of mixed-species flocks in a Sri Lankan rainforest. Forktail 20: 63-70.

34. Goodale E. \& Kotagama S.W. (2005). Testing the roles of species in mixed-species bird flocks of a Sri Lankan rainforest. Journal of Tropical Ecology 21: 669-676.

35. Goodale E. \& Kotagama S.W. (2007). Some observations on the geographic variation of mixed-species bird flocks in Sri Lanka. Journal of the Bombay Natural History Society 104: 96-98.

36. De Silva A. (2006). Current status of the reptiles of Sri Lanka. In: Fauna of Sri Lanka: Status of Taxonomy Research and Conservation. (Ed. C.N.B. Bambaradeniya) pp. 134-163, The World Conservation Union, Colombo and Government of Sri Lanka.

37. Pethiyagoda R. (1994). Threats to the indigenous freshwater fishes of Sri Lanka and remarks on their conservation. Hydrobiologia 285:189-201.

38. Wikramanayake E.D. \& Moyle P.B. (1989). Ecological structure of tropical fish assemblages in wet zone streams of Sri Lanka. Journal of Zoology, London 218: 503-526.

39. Amerasinghe U.S., Shirantha R.R.A.R. \& Wijeratne M. J. S. (2006). Some aspects of ecology of endemic freshwater fishes of Sri Lanka. In: Fauna of Sri Lanka: Status of Taxonomy Research and Conservation (Ed.C.N.B. Bambaradeniya) pp. 113 - 124, The World Conservation Union, Colombo and Government of Sri Lanka.

40. Pethiyagoda R. \& Manamendra-Arachchi K. (1998). Evaluating Sri Lanka's amphibian diversity. Occasional Papers of the Wildlife Heritage Trust 2: 1-12.

41. Manamendra-Arachchi K. \& Pethiyagoda R. (2005). The Sri Lankan shrub frogs of the genus Philautus Gistel, 1848 (Ranidae: Rhacophorinae), with description of 27 new species. In: Contributions to Biodiversity Exploration in Research in Sri Lanka. (Eds. D.C.J. Yeo, P.K.L. Ng \& R. Pethiyagoda) The Raffles Bulletin of Zoology, Supplement No. 12: 5 - 145.

42. Meegaskumbura M., Bossuyt F., Pethiyagoda R., Manamendraarachchi K., Bahir M., Milinkovitch M.C. \& Schneider C.J. (2002). Sri Lanka: an amphibian hotspot. Science 298 (5592): 379

43. Perera W. P. N. \& Bambaradeniya C. N. B. (2006). Species richness, distribution and conservation status of butterflies in Sri Lanka. In: Fauna of Sri Lanka: Status of Taxonomy Research and Conservation. (Ed. C.N.B. 
Bambaradeniya) pp.53-64. The World Conservation Union, Colombo, and Government of Sri Lanka.

44. d' Abrera B. (1998). The Butterflies of Ceylon. pp 224. Wildlife Heritage Trust, Sri Lanka, 95, Cotta Road, Colombo 8.

44a. Gamage R. (2007). An Illustrated Guide to the Butterflies of Sri Lanka. pp 264. Tharanjee Prints, Nawinna.

45. Benjamin S. P. \& Bambaradeniya C. N. B. (2006). Systematics and conservation of spiders in Sri Lanka: current status and future prospects. In: Fauna of Sri Lanka: Status of Taxonomy Research and Conservation. The World Conservation Union, Colombo and Government of Sri Lanka.

46. Dias R.K.S. (2002). Current knowledge on ants of Sri Lanka. ANet Newsletter 4 : 17-20.

47. Gunawardene N.R., Daniels A. E. D., Gunatilleke I. A. U. N., Gunatilleke C. V. S., Karunakaran P. V., Nayak K. G., Prasad S., Puyravaud P., Ramesh B. R., Subramanian K. A. \& Vasanthy G. (2007). A brief overview of the Western Ghats - Sri Lanka biodiversity hotspot. Current Science 93(11): 1567 - 1572.

48. Bahir M.M., Ng P.K.L., Crandall K. \& Pethiyagoda R. (2005). A conservation assessment of the freshwater crabs of Sri Lanka. In: Contributions to Biodiversity Exploration and Research in Sri Lanka. (Eds. D.C.J. Yeo, P.K.L. Ng \& R. Pethiyagoda). The Raffles Bulletin of Zoology, Supplement No.12: 121 - 126.

49. Naggs F.D., Ranawana K. \& Mapatuna Y. (2005). The Darwin Initiative Project on Sri Lankan land snails: patterns of diversity in Sri Lankan forests.Contributions to Biodiversity Exploration in Research in Sri Lanka. (Eds. D.C.J. Yeo, P.K.L. Ng \& R. Pethiyagoda) The Raffles Bulletin of Zoology, Supplement No.12: 23 - 29.

50. Naggs F.D. \& Raheem D. (2000). Land Snail Diversity in Sri Lanka. Natural History Museum, London. CD ROM.

51. Greller A.M., Gunatilleke I.A.U.N., Jayasuriya A.H.M., Gunatilleke C.V.S., Balasubramaniam S. \& Dassanayake, M.D. (1987). Stemonoporus dominated montane forests in the Adam's Peak Wilderness, Sri Lanka. Journal of Tropical Ecology 3(1):243-253.

52. Jayasuriya A.H.M., Greller A.M., Balasubramaniam S., Gunatilleke C.V.S., Gunatilleke I.A.U.N. \& Dassanayake M.D. (1993). Phytosociological studies of the mid-elevational (lower montane) evergreen forests in Sri Lanka. In: Ecology and Landscape Management in Sri Lanka pp. 79-94 (Eds. W. Erdelen, C. Preu, N. Ishwaran \& C.M. Madduma Bandara) Proceedings of the International and Interdisciplinary Symposium, Colombo, Weikersheim:Margraf, Germany.

53. Sinhakumara B.M.P. (1995). Floristic Survey of Adam's Peak Wilderness. pp 156. Forest Department of Sri Lanka, Battaramulla.

54. Gunatilleke I.A.U.N., Greller A.M., Jayasuriya A.H.M., Gunatilleke C.V.S. \& Balasubramaniam S. (1996). Vegetation of the Peak Wilderness and its conservation. Phyta (Journal of the Botanical Society, University of Peradeniya) 4(1): 1-9.
55. Gunatilleke I.A.U.N., Gunatilleke C.V.S. \& Dilhan M.A.A.B. (2005). Plant biogeography and conservation of the South-western hill forests of Sri Lanka. The Raffles Bulletin of Zoology, Supplement No.12: 147-160.

56. Kostermans A. J. G. H. (1992). A Handbook of the Dipterocarpaceae of Sri Lanka.pp. 224. Wildlife Heritage Trust of Sri Lanka, 95, Cotta Road, Colombo 08.

57. Rubasinghe S.C.K. (2007). Species limits and phylogenetics of the endemic genus Stemonoporus (Dipterocapaceae). M.Phil. Thesis, University of Peradeniya, Peradeniya.

58. Ekanayake S.P. (1994). A Phytosociological study of semi-evergreen forests of the Knuckles and Udawalawe, Sri Lanka. M.Phil. Thesis, University of Peradeniya, Peradeniya.

59. O'Shea B.J. (2002). Checklist of the mosses of Sri Lanka. Journal of the Hattori Botanical Laboratories 92: 125 164.

60. O'Shea B. J. (2003). Bryogeographical relationships of the mosses of Sri Lanka. Journal of the Hattori Botanical Laboratories 93: 293 - 304.

61. Balasubramaniam S., Ratnayake S. A. \& White R. (1993). The montane forests of the Horton Plains Nature Reserve. In: Ecology and Landscape Management in Sri Lanka (Eds. W. Erdelen, C. Preu, N.Ishwaran, C.M. Madduma Bandara) pp. 95-108. Proceedings of the International and Interdisciplinary Symposium, Colombo, Weikersheim:Margraf, Germany.

62. Wijesundara D.S.A. (1991). Phytosociology of a montane forest in Sri Lanka. M. Phil Thesis, University of Peradeniya, Peradeniya.

63. Ratnayake H.D. (2005). Some aspects of the vegetation in the Knuckles ecosystem. Lyriocephalus Special Issue 6(1 \& 2):233 - 266.

64. Perera W.R.H. (1978). Thotapolakanda: an environmental disaster. The Sri Lanka Forester 13 (3 \&4): 53-55.

65. Werner W. L. (1988). Canopy die-back in the upper montane rain forests of Sri Lanka. Geojournal 17 (2): 245-248.

66. Adikaram N.K.B., Ranawana K.B. \& Weerasuriya A. (2006). Forest Die Back in the Horton Plains National Park. pp. 54. Department of Wildlife Conservation, No. 18, Gregorys Road, Colombo 07.

67. Werner W.L. (1982).The upper montane forests of Sri Lanka. The Sri Lanka Forester 15: 119 - 135.

68. de Silva A., Ranawana K. B. \& Goonewardene S. (2005). Some observations of the mollusks of the Knuckles massif. In: The Diversity of the Dumbara Mountains. (Ed. A. de Silva) Lyriocephalus Special Issue 6 (1 \&2). $179-182$.

69. de Silva A. (2006). Current status of the reptiles of Sri Lanka. In: Fauna of Sri Lanka: Status of Taxonomy Research and Conservation. (Ed. C.N.B. Bambaradeniya) pp. 134-163. The World Conservation Union, Colombo, and Government of Sri lanka.

70. Manamendra-Arachchi K. \& Pethiyagoda R. (2005). The Sri Lankan shrub frogs of the genus Philautus Gistel, 1848 (Ranidae: Rhacophorinae), with description of 27 
new species. The Raffles Bulletin of Zoology, Supplement No. 12: 163 - 303.

71. Meegaskumbura M. \& Manamendra-Arachchi K . (2005). Description of eight new species of shrub frogs (Ranidae: Rhacophorinae: Philautus) from Sri Lanka. The Raffles Bulletin of Zoology, Supplement No. 12: 305 - 338.

72. Cai Y. \& Bahir M. M. (2005). Lancaris, a new genus of freshwater shrimp from Sri Lanka (Crustaceae: Deacapoda: Atyidae). The Raffles Bulletin of Zoology, Supplement No. 12: 39-46.

73. Bahir M. \& Ng P.K.L. (2005). Description of ten new species of freshwater crabs (Crustacea: Brachyura: Parathelphusidae: Ceylonthelphusa, Mahatha, Perbrinckia) from Sri Lanka. The Raffles Bulletin of Zoology, Supplement 12: 47-75.

74. Sriyani W. M., Padmalal U. K. G. K. \& Kotagama S. (2005). A study of mixed species bird flocks of submontane wet evergreen forest in the northern flank of the Knuckles region in Sri Lanka. In: The Diversity of the Dumbara Mountains. (Ed. A. Silva) Lyriocephalus Special Issue 6 (1 \&2): 277 - 284.

75. Nizam B.Z., Padmalal U.K.G.K. \& Kotagama S. (2005). Amphibian species diversity along the northern flank of the Knuckles range Sri Lanka. In: The Diversity of the Dumbara Mountains. (Ed. A. Silva) Lyriocephalus Special Issue 6(1\&2): $267-273$

76. de Silva A. (2005). The Diversity of the Dumbara Mountains. Lyriocephalus Special Issue 6 (1 \&2): 382.

77. Ashton P.S. (1980). Dipterocarpaceae. In: $A$ Revised Handbook to the Flora of Ceylon. Vol.1. (Eds. M. D. Dasanayake \& F. R. Fosberg), pp. 364 -423.

78. Ranawana K.B., Ekanayake S.P., Gunatilleke I.A.U.N., Gunatilleke C.V.S., Herath H.M.D.R., Jayasena H. A. H., Perera W., Rajapakse H. A. \& Ranasingha M. (1997). Resource Inventories for Protected areas: Victoria - Randenigala- Rantambe Sanctuary. A Global Environment Facility Project. Final Report submitted to the Department of Wildlife Conservation, Sri Lanka. pp. 310

79. Gunawarddena N.P.T. \& Gunatilleke C.V.S. (1996). The understorey vegetation at Samanalawewa in Sri Lanka. Phyta (Journal of the Botanical Society, University of Peradeniya) 4 (1): 18-33.

80. Weerasinghe, U.R. (1999). Seasonal resource use of large herbivorous mammals in the Wasgomuwa National Park, Sri Lanka. Ph. D. Thesis, University of Tokyo, Japan.

81. Jayasingam T. \& Vivekanantharaja S. (1994). Vegetation survey of the Wasgomuwa National Park, Sri Lanka: analysis of the Wasgomuwa Oya Forest. Plant Ecology 113 (1): 1-8.

82. Jayasingam T., Vivekanantharajah K. \& Balasubramaniam S. (1992). Vegetation survey of the Wasgomuwa National Park: Reconnaissance. Vegetatio 101: 171-181.

83. Liyanage S. (1998). Floristic structure and aspects of regeneration of tree species in the Kahalla Forest Reserve. M. Phil. Thesis, University of Peradeniya, Peradeniya.

84. Fernando H.S.K. (1996). A comparative study on the ecology of woody vegetation of forest types in the
Maduru Oya National Park. M. Phil Thesis, University of Peradeniya, Peradeniya.

85. Jayasuriya A.H.M. (1980). Studies on the flora and ecology of Ritigala Strict Natural Reserve. M. Phil. Thesis, University of Peradeniya, Peradeniya.

86. Jayasuriya A.H.M. (1984). Flora of Ritigala Natural Reserve. Sri Lanka Forester 16: 60-156.

87. Jayasuriya A.H.M. \& Pemadasa M.A. (1983). Factors affecting the distribution of tree species in a dry zone montane forest in Sri Lanka. Journal of Ecology 71: 571-583.

88. Dilhan M.A.A.B. (2005). Vegetation structure and floristic composition in the irrigation extension area of the Lower Walawe Basin, Sri Lanka. M.Phil. Thesis, University of Peradeniya, Peradeniya.

89. Dittus W.P.J. (1985). The influence of cyclones on the dry evergreen forest of Sri Lanka. Biotropica 17: 1-14.

90. Dittus W.P.J. (1977). The ecology of a semi-evergreen forest community in Sri Lanka. Biotropica 9: 268-286.

91. Dilhan M.A.A.B., Yakandawela D., Gunatilleke C.V.S., \& Bambaradeniya C.N.B. (2002). Structure and composition of scrubland vegetation in the Lower Walawe Basin irrigation extension area in Sri Lanka. Ceylon Journal of Science 30: 105 -124.

92. Sathurusinghe A. (1985). Phytosociological analysis of vegetation of Wilpattu National Park. M. Sc. Dissertation University of Sri Jayawardenapura, Gangodawila, Nugegoda.

93. de Silva M. \& de Silva P.K. (2004). The Yala Wildlife Reserves: Biodiversity and Ecology. pp. 227, Wildlife Trust Publications Ltd., Colombo.

94. Mueller-Dombois D. (1972). Crown distortion and elephant distribution in the woody vegetation of Ruhuna National Park Ceylon. Ecology 53(2): 208-226.

95. Bambaradeniya C.N.B., Ekanayake S.P., Fernando R.H.S.S., Perera W.P.N. \& Somaweera R. (2002). A biodiversity status profile of Bundala National Park: a Ramsar Wetland in Sri Lanka. Occasional Papers of IUCN Sri Lanka No.2, pp. 37.

96. Mueller-Dombois D. (1968). Ecogeographic analysis of a climate map of Ceylon with special reference to vegetation. Ceylon Forester 8: 39 - 58.

97. Pemadasa M. A. (1984). Grasslands. In: Ecology and Biogeography in Sri Lanka. (Ed. C.H. Fernando) pp. 453492. W. Junk Publishers.

98. de Silva A. (2007). The Diversity of Horton Plains National Park (with Special Reference to its Herpetofauna). pp. 273. Vijitha Yapa Publications, Colombo.

99. Mueller-Dombois D. \& Perera Malini. (1971). Ecological differentiation and soil fungal distribution in the montane grasslands of Ceylon. Ceylon Journal of Science 9(1): 1-41.

100. Pemadasa M. A. \& Mueller Dombois D. ( 1981). An association-analysis of montane grasslands of Sri Lanka. Australian Journal of Ecology 6: 111-121.

101. Amarasinghe L. (1979).Ecology of grassland vegetation of Hantana hills. M. Phil. Thesis, University of Peradeniya, Peradeniya. 
102. Pemadasa M.A. \& Amarasinghe L. (1982). Ecology of a montane grassland in Sri Lanka I. Quantitative description of the vegetation. Journal of Ecology 70: 1-15.

103. Ashton P.M., Samarasinghe S.J., Gunatilleke I.A.U.N. \& Gunatilleke C.V.S. (1997). Role of legumes in release of successionally arrested grasslands in the Central Hills of Sri Lanka. Restoration Ecology 5(1): 36-43.

104. Kularatne H.A.G.C., Herath H.M.P.C., Gunatilleke C.V.S. \& Gunatilleke I.A.U.N. (1998). Towards park management of the Victoria-Randenigala-Rantembe (VRR) Sanctuary: Post-fire early successional vegetation dynamics. Proceedings of the Final Workshop of the University of Peradeniya-Oxford Forestry Institute Link Project. pp. 127-152.

105. Kularatne H.A.G.C., Gunatilleke I.A.U.N. \& Gunatilleke C.V.S. (1996). Phenology of some savanna tree species at Victoria-Randenigala Sanctuary. (Ed. H.P.M. Gunasena). Proceedings of the Phase I Review sSeminar Workshop of the UP-OFI Link Project. University of Peradeniya, pp. 3-32.

106. Kularatne H.A.G.C., Gunatilleke C.V.S., Gunatilleke I.A.U.N. \& Brown N.D. (1998). Towards park management of the Victoria-Randenigala-Rantembe (VRR) Sanctuary: soil seed bank studies in the fire affected sites. (Ed. H.P.M. Gunasena). Proceedings of the Final Workshop of the University of Peradeniya-Oxford Forestry Institute Link Project. pp. 102-126.

107. Russel-Smith J., Karunaratne N. \& Mahindapala R. (2006). Rapid inventory of wild medicinal plant populations in Sri Lanka. Biological Conservation 132(1): 22-32.

108. Szechowyez R.W. (1961 ). The savanna forest of the Gal Oya catchment (Ceylon). The Ceylon Forester 5(1\&2): 17-22.

109. Koelmeyer K.O. (1957). Climatic classification and the distribution of vegetation in Ceylon. The Ceylon Forester 3(2): 144-163.

110. Jansen M. (1981). Villus of the floodplains of the Mahaweli ganga. Loris 15(6): 337-340.

111. Jansen M. (1987). Wetland habitats of the Mahaweli ganga flood plain. Loris 17(5): 186-191.

112. Seneviratne L. K., Ginige P., Dayananda M. D. \& Gamlath D. (1994). Wetland Site Report, Walauwatta Waturana Swamp Forest Wetland Conservation Project. pp. 54. Central Environmental Authority (Sri Lanka)/ Euroconsult, The Netherlands.

113. Starmulhner F. (1984). Mountain stream fauna with special reference to the mollusca. In. Ecology and Biogeography of Sri Lanka. (Ed. C.H. Fernando) pp. 215-252.

114. Costa C.H. (1984). The ecology and distribution of free living meso and macrocrustacea of inland waters. In: Ecology and Biogeography of Sri Lanka. (Ed. C.H. Fernando) pp. 195-213.

115. Schiemer F., Amarasinghe U.S., Frouzova J., Sricharoendham B. \& Silva E.I.L. (2001). Ecosystem structure and dynamics - A management basis for Asian reservoirs and lakes. In: Reservoir and culturebased fisheries: biology and management. Proceedings of an International Workshop, February 15-18, 2000, Bangkok. held in Bangkok, ACIAR Proceedings No. 98: 215-226.

116. Fernando C.H. \& de Silva S.S. (1984). Man made lakes: ancient heritage and modern biological resource. In: Ecology and Biogeography of Sri Lanka. (Ed. C.H. Fernando). pp. 431-451.

117. The World Conservation Union, Sri Lanka (2007). The 2007 List of Threatened Fauna and Flora of Sri Lanka. pp. 148. IUCN, 53, Horton Place, Colombo 07.

118. Shafer-Fehre M. (2006). A Revised Handbook to the Flora of Ceylon. Vol. 15 (Part A:) Ferns and Fern-Allies. pp.310. Science Publishers, Enfield, USA.

119. Abeywickrama B.A. (1979). The Genera of the Fresh Water Algae of Sri Lanka Part 1. pp. 103. National Science Council of Sri Lanka, 47/5, Maitland Place, Colombo 07.

120. Coomaraswamy U. (1979a). A Handbook to the Fungi Parasitic on the Plants of Sri Lanka pp. 169. National Science Council of Sri Lanka. 47/5, Maitland Place, Colombo 07.

121. Coomaraswamy U. (1979b). A Handbook to the Agaricus of Sri Lanka, pp 68. National Science Council of Sri Lanka, 47/5, Maitland Place, Colombo 07.

122. Coomaraswamy U. (1983). A Handbook to the Fungi Associated with Insects of Sri Lanka, pp. 72. National Science Council of Sri Lanka, 47/5, Maitland Place, Colombo 07.

123. Coomaraswamy U. \& Kumarasingham S. (1988). A Handbook to the Macrofungi of Sri Lanka, pp. 124. Natural Resources, Energy and Science Authority, Sri Lanka, 47/5, Maitland Place, Colombo 07.

124. Bambaradeniya C.N.B. (2006). Fauna of Sri Lanka: Status of Taxonomy, Research and Conservation. pp. 308. The World Conservation Union, Colombo and Government of Sri Lanka.

125. Hale M. E. (1981). A revision of the lichen family Thelotremataceae in Sri Lanka. Bulletin of the British Museum of Natural History (Botany Series.) 8(3): 227-332.

126. Anonymous (1991). Natural Resources of Sri Lanka: Conditions and Trends. pp. 280. Natural Resources, Energy and Science Authority of Sri Lanka, 47/5, Maitland Place, Colombo 07.

127. Miththapala S., Seidensticke J., Coomaraswamy U., \& Kumarasingham S., O'Brien S. J. (1996). Phylogeographic subspecies recognition in leopards (Panthera pardus): molecular genetic variation. Conservation Biology 10 (4):1115-1132

128. Uphyrkina O., Johnson W E., Quigley H., Miquelle D. M. L., Bush M. \& O’ Brien S. J. (2001). Phylogenetics, genome diversity and origin of modern leopard, Panthera pardus. Molecular Ecology 10: 2617-2633.

129. Fernando P., Pfrender M. E., Encalada S. E \& Lande, R. (2000). Mitochondrial DNA variation, phylogeography and population structure of the Asian elephant. Heredity 84(3): 362-372. 
130 Gower D.J., Bahir M.M., Mapatuna Y., Pethiyagoda R., Raheem D. \& Wilkinson M. (2004). Molecular phylogeny of Sri Lankan ichthyophis (Amphibia: Gymnophiona:Ichthyophiidae) with discovery of a cryptic species. Raffles Bulletin of Zoology Supplement No. 12: 153-161.

131 Murawski D.A., Dayanandan B. \& Bawa K.S. (1994a). Outcrossing rates of two endemic Shorea species from Sri Lankan tropical rain forests. Biotropica 26 : 23-29.

132 Murawski D.A., Gunatilleke I.A.U.N. \& Bawa K.S. (1994c). The effects of selective logging on inbreeding in Shorea megistophylla (Dipterocarpaceae) from Sri Lanka. Conservation Biology 8: 997-1002.

133 Murawski D.A. \& K.S. Bawa (1994b). Genetic structure and mating system of Stemonoporus oblongifolius (Dipterocarpaceae) in Sri Lanka. American Journal of Botany 81:155-160.

134 Gamage D.T., Silva M.P., Yoshida A., Szmidt A.E. \& Yamazaki T. (2003). Molecular phylogeny of Sri Lankan Dipterocarpaceae in relation to other Asian Dipterocarpaceae based on chloroplast DNA sequences. Tropics 13: 79-87.

135 Stacy E.A. (2001). Cross-fertility in two tropical tree species: evidence of inbreeding depression within populations and genetic divergence among populations. American Journal of Botany 88: 1041-1051.

136 Ratnayake R.M.C.S., Su Y.C.F., Gunatilleke I.A.U.N., Wijesundera D.S.A. \& Saunders R.M.K. (2006). Reproductive biology of two sympatric species of Polyalthia (Annonaceae) in Sri Lanka II. Breeding systems and population genetic structure. International Journal of Plant Science 167: 495-502.

137 Anonymous (2007). FAO/Government Co-operative Programme: Final Report on the establishment of the National Information Sharing Mechanism (NISM) on the Implementation of the Global Plan of Action for the Conservation and Utilization of Plant genetic Resources for Food and Agriculture in Sri Lanka (Eds. D.H. Muthukuda Arachchi, C.S. Weeraratna \& L. Amarasinghe) AG: GCP/RAS/186/JPN Field Document No. 2007/03. pp. 189.

138 Wijesinghe L.C.A. de S., Gunatilleke I.A.U.N., Jayawardana S.D.G., Kotagama S. W., Gunatilleke, C.V.S. (1993). Biological Conservation in Sri Lanka: A National Status Report. The World Conservation Union, 53 Horton Place, Colombo 07.

139 Anonymous (1996). An investment proposal for the conservation and sustainable use of medicinal plants in Sri Lanka IUCN Sri Lanka, Colombo.

140 Myres N., Mittermeier R. A., Mittermeier C., Da Fonseca G. A. R. \& Kent J. (2000). Biodiversity hotspots for conservation priorities. Nature 403: 853-858.

141 Olson S., Sadacharan D., Samarakoon J.I., White A.T., Wickramaratne H.J.M. \& Wijeratne M.S. (1992). Coastal 2000: Recommendations for a Resource Management Strategy for Sri Lanka's Coastal Region. Coast Conservation Department \& Coastal Resources Center, The University of Rhode Island, USA.
142 Rajasuriya A. (2002). Status Report on the condition of reef habitats in Sri Lanka. In: Coral Reef Degradation in the Indian Ocean Status Report.(Eds. O. Lindon, D. Souter, D. Wilhelmsson \& D. Obura) pp. 139-148 CORDIO, University of Kalmar, Sweden.

143 Lindon O., Souter D., Wilhelmsson D. \& Obura D. (2002). Coral Reef Degradation in the Indian Ocean Status Report. CORDIO, University of Kalmar, Sweden.

144 Fernando P., Wikramanayake E.D. \& Pastorini J. (2006). Impact of tsunami on terrestrial ecosystems of Yala National Park, Sri Lanka. Current Science 90: 15311534.

145 Perera N. P. (1984). Natural resources, settlements and land use. In: Ecology and Biogeography of Sri Lanka. (Ed. C.H. Fernando) pp. 453 - 492.

146 Pethiyagoda R. (2007). Pearls, Spices and Green Gold: An Illustrated History of Biodiversity Exploration in Sri Lanka. pp. 241. Willife Heritage Trust, Publications Pvt. Ltd., Colombo.

147 Karunaratne N. (1987). Forest Conservation in Sri Lanka from British Colonial Times 1818 - 1982. pp. 101. Trumpet Publishers Pvt Ltd., Colombo.

148 Gunatilleke C.V.S. Gunatilleke I.A.U.N. (1983). A forestry case study of the Sinharaja rain forest in Sri Lanka. In: Forest and Watershed Development and Conservation in Asia and the Pacific. (Ed. L.Hamilton) pp. 289-358. Westview Press, Colorado, USA

149 Perera G.A.D. (2001). The secondary forest situation in Sri Lanka: a review. Journal of Tropical Forest Science 13(4): 768-785.

150 Jayaweera D.M.A. (1981-1982). Medicinal Plants Used in Ceylon. Parts 1-5. National Science Council, 47/5, Maitland Place, Colombo 07.

151 McDermott M., Gunatilleke C.V.S. \& Gunatilleke I.A.U.N. (1990a). The Sinharaja rain forest: conserving both biological diversity and a way of life. The Sri Lanka Forester 19 (3\&4): 3-22.

152 Mc Dermott, M., Gunatilleke C.V.S. \& Gunatilleke I.A.U.N. (1990b). The Sinharaja rain forest: the compatibility of biological and cultural conservation. The Sri Lanka Forester 22: 3-28.

153 Gunatilleke I.A.U.N. \& Gunatilleke C.V.S. (1993). Underutilized food plant resources of Sinharaja rain forest in Sri Lanka. In: Food and Nutrition in the Tropical Rain Forest: Bicultural Interactions, (C.M. Hladik, A. Hladik, H. Pagazy. O.F. Linaries \& M. Hadley). Man and Biosphere Series, Vol.15, UNESCO, Paris and Parthenon Publishing, Carnforth, UK. pp. 183-198

154 de Zoysa N. \& Vivekanandan K. (1994). Rattans of Sri Lanka: an illustrated field guide pp. 82. Forest Department, Sri Lanka.

155 Ashton, Mark S., Gunatilleke Savitri., De Zoysa Neela., Gunatilleke Nimal., Dassanayake M.D. \& Wijesundera Siril (1997). A Field Guide to the Common Trees and Shrubs of Sri Lanka. pp. 431. The Wildlife Heritage Trust of Sri Lanka.

156 Rajapakse L.K., Padmalal U.K.G.A. \& Kotagama S.W. (2002). Impact of sambar deer (Cervus unicolor 
unicolor) on the vegetation at the Horton Plains National Park. Proceedings of the eighth annual forestry and environment symposium 2002, Dept. of Forestry and Environmental Science, University of Sri Jayawardenepura, Gangodawila, Nugegoda.

157 Padmalal U.K.G.A., Takatsuki S. \& Jayasekara P. (year) Food habits of sambar Cervus unicolor at the Horton Plains National Park, Sri Lanka. Ecological Research 18(6): 775 - 782 .

158 Gunawardana E.R.N., Rajapakse U., Nanadasena K.A., Rosier P.T.W Chandrasiri N. (1998) Water quality use in the uplands of Sri Lanka, (Ed. H.P.M. Gunasena) In: Proceedings of the Final Workshop University of Peradeniya-Oxford Forestry Institute Link Project. pp. 37-44.
159 Anonymous (1999). Biodiversity Conservation in Sri Lanka: A Framework for Action. pp.126. Ministry of Forestry and Environment, Battaramulla.

160 Ekaratne K., Fernando R.H.S.S., de Silva S., Bambaradeniya C. M. B. \& de Silva D. (2003). A Comparison of the Conservation and Legal Status of the Fauna and Flora of Sri Lanka. pp. 163. IUCN Sri Lanka, Colombo.

161 Anonymous (2003). Caring for the Environment 2003 2007: Path to Sustainable Development pp. 152. Ministry of Environment and Natural Resources, Battaramulla .

162 Anonymous (2007). The UN Decade of Education for Sustainable Development (DESD 2005 - 2014) the First Two Years. Pp. 64. UNESCO, France.

163. UNESCO (2007). Biodiversity in UNESCO, pp. 32. UNESCO, Paris. 